\title{
Phylogenetic and Morphological Reassessment of Mycosphaerella nawae, the Causal Agent of Circular Leaf Spot in Persimmon
}

Oliul Hassan and Taehyun Chang, ${ }^{\dagger}$ Department of Ecology \& Environmental System, College of Ecology \& Environmental Sciences, Kyungpook National University, Sangju-si, Gyeongsangbuk-do, 37224, Korea (Republic of)

\begin{abstract}
Persimmon (Diospyros kaki) fruit production is severely affected by circular leaf spot worldwide. Mycosphaerella nawae causes circular leaf spot of persimmon (CLSP) and can result in leaf spot, defoliation, early fruit maturation, and subsequent softening and abscission. The morphology and phylogenetic position of M. nawae within the family Mycosphaerellaceae is, therefore, of utmost importance given its impact on persimmon production. Based on previous morphological and molecular studies, the phylogenetic position of the anamorphic genera associated with $M$. nawae remain in confusion. In the present study, 15 isolates of $M$. nawae were collected from the tissue of living leaves exhibiting leaf spot symptoms. A subsample of three isolates was characterized phylogenetically and morphologically.

Isolates were compared based on DNA sequence data for the internal transcribed spacer region (ITS1-5.8S ITS2), part of the 28S nrDNA including domains D1-D3 (LSU), actin (Act), translation elongation factor 1-alpha (EF-1 $\alpha$ ), and RNA polymerase II second largest subunit (rpb2). The anamorph and teleomorph structures, ascospore germination patterns, as well as host specificity were used to describe the isolates. The phylogenetic and morphological analyses revealed that $M$. nawae requires a new holomorphic genus within Mycosphaerellaceae, described herein as Plurivorosphaerella gen. nov. A host specificity test revealed that Plurivorosphaerella nawae comb. nov. (M. nawae) can superficially colonize, but not infect, apple, peach, cherry, and plum.
\end{abstract}

Mycosphaerella comprises one of the largest generic complexes of plant-pathogenic ascomycetes. Although most of the Mycosphaerella species are known as foliicolous plant pathogens, some are responsible for stem cankers and fruit lesions (Cortinas et al. 2006; Crous 2009; Crous et al. 2001; Pretorius et al. 2003). Being saprobic, plant pathogens to hyperparasites, endophytes, and symbionts, Mycosphaerella spp. are able to survive in various ecosystems (Crous et al. 2001; Quaedvlieg et al. 2012). Mycosphaerella spp. are plant pathogens that cause significant economic losses of both temperate and tropical crops worldwide, including banana, cereals, sugar beet, strawberry, soybean, citrus, eucalyptus, acacia, pines, guava, and persimmon (Crous 2009; Crous and Braun 2003; Jacobs et al. 2014; Kwon et al. 1998a). Teleomorph morphology of Mycosphaerella is relatively simple and conserved, but 30 anamorphic genera have been associated with this generic complex (Crous 2009; Crous et al. 2007b). The phylogenetic relationships of numerous Mycosphaerella species and their anamorphs based on multigene sequences revealed that the Mycosphaerella complex is in fact poly- and paraphyletic (Crous 2009; Crous et al. 2007a; Hunter et al. 2006). For this reason, taxonomic redistribution is needed for most of the phylogenetic clades within the complex (Crous 2009; Quaedvlieg et al. 2012). The dual nomenclature within the Mycosphaerella complex based on teleomorphs and anamorphs is confusing and complicated. Videira et al. (2017) recently split the whole complex into numerous genera based on results of phylogenetic multigene analyses reflecting that traditional morphological approaches are not tenable for taxonomic purposes within Mycosphaerellaceae. Mycosphaerella nawae, the

${ }^{\dagger}$ Corresponding author: T. Chang; E-mail: thchang@knu.ac.kr

Funding: This study was supported by a grant from the Cooperative Research Program for Correspondence Competitiveness Improvement Technology Development (Project No. PJ01169703) of the Rural Development Administration, Korea.

Accepted for publication 11 July 2018.

C 2019 The American Phytopathological Society causal agent of circular leaf spot of persimmon (CLSP), is a great threat to the persimmon industry. Fruit production is affected by early fruit maturation and subsequent softening and abscission, along with foliar symptoms and defoliation (Bassimba et al. 2017; Berbegal et al. 2010). The morphology of $M$. nawae in different pathosystems has been the focus of many studies (Berbegal et al. 2010; Ikata and Hitomi 1929; Kwon et al. 1998a, b; Lee et al. 2016). All authors agree that the teleomorph of M. nawae, consists of small, black, spherical fruiting bodies (pseudothecia), cylinder- or banana-shaped asci, and uniseptate and mostly spindle-shaped ascospores (Berbegal et al. 2010; Kwon et al. 1998c; Lee et al. 2016). Kwon et al. (1998a, b) detailed the anamorph of $M$. nawae and the ability of asexual conidia to infect persimmon leaves. The authors suggested that the anamorph of M. nawae is linked to the genus Ramularia based on its morphological characteristics. Asexual conidia were of various shapes and sizes and were formed solitarily or in chains on potato dextrose agar (PDA) and on infected leaves (Kwon et al. 1998a, b). Multigene sequence data revealed that the morphological characteristics used to define the anamorph are not always informative (Verkley et al. 2004). Lee et al. (2016) analyzed the phylogenetic relationships of $M$. nawae and allied species by using multilocus gene sequences and identified $M$. nawae as the closest species to members of the genus Phaeophleospora, especially P. scytalidii, although $M$. nawae belongs to a clade distinct from $P$. scytalidii. These authors were not able to show sufficient evidence in the characteristics of the anamorph to support the phylogenetic relationships. The dilemma regarding the taxonomic positioning of the anamorph of $M$. nawae remains unresolved. Persimmon (Diospyros kaki) has been reported as the only host for M. nawae (Kwon et al. 1998c). However, there is little data available to support this hypothesis. Recent studies based on molecular data indicate that some species of Mycosphaerella have narrow host ranges, while others have wider host ranges (Crous and Groenewald 2005; Crous et al. 2006, 2009d). Host-specific Mycosphaerella species may jump from a dying host to a nonhost and produce progeny that then may infect another favorable host (Crous and Groenewald 2005). Therefore, M. nawae could have a secondary host or may switch to secondary hosts in the absence of persimmon leaves.

The aims of this study were to (a) re-evaluate the morphological (teleomorph and anamorph) and molecular characteristics of 
M. nawae, (b) clarify the phylogeny and generic taxonomy, and (c) evaluate the pathogenicity and host specificity of $M$. nawae.

\section{Materials and Methods}

Isolation and preliminary identification of M. nawae. A total of 15 isolates associated with CLSP symptoms in persimmon leaves were collected from five different orchards located in Sanju, Korea. The isolates were recovered from the margins of leaf lesions. Diseased leaves were surface disinfected with $95 \%$ ethanol and washed using distilled water. Small sections $\left(1 \mathrm{~cm}^{2}\right)$ were cut from the affected leaf tissue and disinfested with $0.5 \%$ sodium hypochlorite solution for $2 \mathrm{~min}$. The sections were then washed three times in sterile distilled water and dried by blotting. Small sections of lesion margins were placed on water ager (WA) supplemented with streptomycin $\left(0.05 \mathrm{~g} /\right.$ liter). Plates were incubated at $25^{\circ} \mathrm{C}$ until fungal hyphae emerged from necrotic tissue. Individual hyphal tips were transferred to fresh PDA after 6-7 days of incubation. To achieve a pure culture, all isolates were hyphal-tipped twice and cultured on PDA. M. nawae isolates were initially identified by morphology, and nested-PCR for specific identification as described by Berbegal et al. (2013). The nested-PCR methods comprised two rounds of amplification. The first round PCR was performed with the universal fungal primers, ITS1F/ITS4, and the second round was performed with the specific primer pair, MNf/MNr (Berbegal et al. 2013). A subsample of three isolates (MN6-1, MN7, and MN10) identified as M. nawae were used for further studies.

Genomic DNA extraction, PCR amplification, purification, and sequencing. Total genomic DNA was extracted from the three isolates using a HiGene Genomic DNA Prep Kit (Yuseong-Gu, Daejeon, Korea) following the manufacturer's instructions. Mycelium from actively growing cultures was used to isolate genomic DNA. The isolation process was confirmed by visualizing DNA in a $1 \%$ agarose gel (wt/vol), stained with loading STAR(6X) (DYENE $\mathrm{BIO})$, and viewed under ultraviolet light. Isolated genomic DNA was used as a template to amplify and sequence the ITS (ITS15.8S ITS2) region, part of the $28 \mathrm{~S}$ nrDNA, including domains D1-D3 (LSU), actin (ACT), RNA polymerase II second largest subunit (rpb2), and translation elongation factor 1-alpha (EF-1 $\alpha)$. The details of the primers used for PCR amplifications are shown in Table 1. PCRs were carried out in a simpliAmp thermal cycler (Thermo Fisher Scientific Inc.). Each $25 \mu$ l PCR mixture was made with $18.2 \mu \mathrm{l}$ of UV-sterilized ultra-filtered water, $2.5 \mu \mathrm{l} 10 \times$ F-star Taq buffer, $0.5 \mu \mathrm{l}$ dNTP Mix (each $10 \mathrm{mM}$ ), $1 \mu \mathrm{l}$ forward primer (10 pmol), $1 \mu l$ reverse primer $(10 \mathrm{pmol}), 1 \mu \mathrm{l}$ genomic DNA, and $0.4 \mu \mathrm{l}$ F-star Taq DNA polymerase (BIOFACT, Korea). PCR cycling conditions were largely identical for selected genes except for the primer annealing step. All of the PCR cycles were run with an initial denaturation step at $95^{\circ} \mathrm{C}$ for $4 \mathrm{~min}$, followed by 34 cycles of denaturation at $95^{\circ} \mathrm{C}$ for $35 \mathrm{~s}$, primer extension at $72^{\circ} \mathrm{C}$ for $35 \mathrm{~s}$, and a final elongation step at $72^{\circ} \mathrm{C}$ for $7 \mathrm{~min}$. The annealing step was adjusted to $52^{\circ} \mathrm{C}$ for ITS, $61^{\circ} \mathrm{C}$ for Act, $62^{\circ} \mathrm{C}$ for LSU, $72^{\circ} \mathrm{C}$ for EF- $1 \alpha$ (Hunter et al. 2006), and $60^{\circ} \mathrm{C}$ for rpb2 (Videira et al. 2017). All of the PCR products were examined by electrophoresis in $1 \%$ agarose gels, and the product of successful reactions was purified using a HiGene PCR Purification Kit (Yuseong-Gu, Daejeon, Korea). Purified double-stranded PCR fragments were sequenced directly using their respective primers at Macrogen, Inc. (Seoul, Korea). The resulting consensus sequences were deposited in GenBank (accession numbers are listed in Table 2).

Phylogenetic analysis. All of the generated sequences (ITS, Act, LSU, EF-1 $\alpha$, and rpb2) were compared with other fungal DNA sequences previously deposited in GenBank using a BLAST search (https://blast.ncbi.nlm.nih.gov/). Gene sequences of $M$. nawae and selected reference type strains belonging to the Mycosphaerellaceae, Teratosphaeriaceae, and Davidiellaceae were retrieved from GenBank (Berbegal et al. 2010; Burgess et al. 2007; Crous et al. 2009d; Hunter et al. 2006; Lee et al. 2016; Videira et al. 2017). Gene sequences of reference type anamorphs linked to Mycosphaerella spp. (Crous et al. 2009c) also were retrieved from GenBank (Table 2). Multiple sequence alignments of sequences generated from the present isolates and those retrieved from GenBank (Table 2) were done using muscle multiple sequence alignment programs of MEGA v. 6.0 (Tamura et al. 2013) and edited manually where necessary. The aligned sequences of each gene were concatenated with Mesquite v. 2.75 (Maddison and Maddison 2011). Maximum likelihood (ML), maximum parsimony (MP), and Bayesian inference (BI) phylogenetic analyses were conducted for the aligned sequence data. ML and MP were performed using MEGA v. 6.0 (Tamura et al. 2013). ML trees were constructed using a Tamura-Nei substitution model with Gamma distributed with Invariant $(\mathrm{G}+\mathrm{I})$ rates among the site. The ML Heuristic search option with Nearest-Neighbor-Interchange (NNI) was used to infer the tree. The 1,000-bootstrap replicates were implemented to assess the relative stability of the branches. The MP tree was obtained using the Subtree-Pruning-Regrafting (SPR) algorithm with search level 1, in which the initial trees were obtained by the random addition of sequences (10 replicates). BI analysis was performed using MrBayes v. 3.2.2 (Ronquist et al. 2012). The Markov Chain Monte Carlo (MCMC) algorithm was used to regenerate the phylogenetic trees. Four Markov chains were run from trees for 2 million random generations. Trees were sampled every 1,000 th generation. The initial $25 \%$ of trees in the burn-in phase of each analysis was discarded, and the remaining trees in each analysis were used to calculate the posterior probabilities in the $50 \%$ majority rule consensus tree. The robustness of each node was examined by posterior probability analysis. The generated phylogenetic trees were viewed in FigTree v 1.3.1 (Rambaut and Drummond 2009).

Morphological analysis. Isolate MN10 was selected for morphological description. To observe colony morphology and the effects of temperature, light, and relative humidity $(\mathrm{RH})$ on mycelial growth, mycelial discs (5 $\mathrm{mm}$ diameter) were removed from the actively growing edge of 4-day-old cultures, and each mycelial disc was placed on a $90 \mathrm{~mm}$ PDA plate. Plates were incubated at $25^{\circ} \mathrm{C}$ in the dark for morphological observation. To evaluate the effects of temperature, light, and $\mathrm{RH}$ on mycelial growth, the plates were incubated under the following conditions: 1) at $5,10,15,20$, and $25^{\circ} \mathrm{C}$ in the dark; 2) at $5,10,15,20$, and $25^{\circ} \mathrm{C}$ under $16 \mathrm{~h}$ of light; and 3 ) at 5 , $10,15,20$, and $25^{\circ} \mathrm{C}$ with $>75 \% \mathrm{RH}$ in the dark. A relative humidity of over $75 \%$ was maintained by keeping the plates with mycelial discs open inside a sterile plastic box containing moist tissue paper. Morphological characteristics were observed and recorded after

Table 1. Details of the primers used in this study, with sequences and sources

\begin{tabular}{lllll}
\hline Locus & Primer name & Direction & \multicolumn{1}{c}{ Primer sequence $\left(\mathbf{5}^{\prime}\right.$-3') } & References \\
\hline ITS & ITS-1F & Forward & CTTGGTCATTTAGAGGAAGTAA & White et al. 1990 \\
& ITS-4 & Reverse & TCCTCCGCTTATTGATATGC & White et al. 1990 \\
LSU & LR0R & Forward & ACCCGCTGAACTTAAGC & Moncalvo et al. 1995 \\
& LR7 & Teverse & TACTACCACCAAGATCT & Vilgalys and Hester 1990 \\
Actin & ACT-512F & Forward & ATGTGCAAGGCCGGTTTCGC & Carbone and Kohn 1999 \\
& ACT-783R & Reverse & TACGAGTCCTTCTGGCCCAT & Carbone and Kohn 1999 \\
EF-1 $\alpha$ & EF1-728F & Forward & CATCGAGAAGTTCGAGAAGG & Carbone and Kohn 1999 \\
& EF1-986R & Reverse & TACTTGAAGGAACCCTTACC & Carbone and Kohn 1999 \\
rpb2 & RPB2-5F2 & Forward & GGGGWGAYCAGAAGAAGGC & Sung et al. 2007 \\
& RPB2-7cR & Reverse & CCCATRGCTTGYTTRCCCAT & Liu et al. 1999 \\
\hline
\end{tabular}


2 weeks of incubation, and colony diameter was recorded for three replicate cultures of isolate MN10, with two measurements per replicate. The diameter of each colony was measured by subtracting the diameter of the 5-mm plug from the two perpendicular diameters, and the obtained measurements were averaged. The effects of different media, including oatmeal agar (OMA), malt agar (MA), low carbon agar (LCA), PDA, V8, and corn meal agar, on the mycelial growth of isolate MN10 were also examined. Mycelial discs (5 mm diameter)

Table 2. Collection details and GenBank accession numbers of the fungal isolates used in this study for molecular data analyses. Ex-type cultures are indicated in bold text.

\begin{tabular}{|c|c|c|c|c|c|c|c|}
\hline \multirow[b]{2}{*}{ Current name } & \multirow{2}{*}{$\begin{array}{l}\text { Previous name } \\
\text { (if different) }\end{array}$} & \multirow[b]{2}{*}{ Isolate no. ${ }^{\mathrm{a}}$} & \multicolumn{5}{|c|}{ GenBank accession number } \\
\hline & & & LSU & ITS & Actin & EF-1 $\alpha$ & rpb2 \\
\hline \multicolumn{8}{|l|}{ Mycosphaerellaceae } \\
\hline Plurivorosphaerella nawae & Mycosphaerella nawae & MN6-1 & LC380932 & LC194865 & LC380938 & LC380935 & LC380941 \\
\hline P. nawae & M. nawae & MN7 & LC380933 & LC194866 & LC380939 & LC380936 & LC380942 \\
\hline P. nawae & M. nawae & MN10 & LC380934 & LC194867 & LC380940 & LC380937 & LC380943 \\
\hline M. nawae & & SJ01 & LC121140 & LC121109 & & & \\
\hline M. nawae & & Jap 01 & LC121154 & LC121123 & & & \\
\hline M. africana & & CBS 116154 & DQ246257 & AF309602 & DQ147609 & DQ235099 & \\
\hline M. africana & & CBS 116155 & DQ246258 & DQ267577 & DQ147608 & DQ235098 & \\
\hline M. ambiphylla & & CBS 110499 & DQ246219 & AY725530 & DQ147669 & DQ235103 & \\
\hline M. aurantia & & CBS 110500 & DQ246256 & AY725531 & DQ147610 & DQ235097 & \\
\hline M. communis & & CBS 114238 & DQ246262 & AY725541 & DQ147655 & DQ235141 & \\
\hline M. communis & & CBS 110976 & DQ246261 & AY725537 & DQ147654 & DQ235140 & \\
\hline M. crystallina & & CMW 3042 & DQ204746 & DQ267578 & DQ147637 & DQ211662 & \\
\hline M. crystallina & & CMW 3033 & DQ204747 & AY490757 & DQ147636 & DQ211663 & \\
\hline M. ellipsoidea & & CMW 4934 & DQ246253 & AF309592 & DQ147647 & DQ235129 & \\
\hline M. ellipsoidea & & CMW 5166 & DQ246254 & AF309593 & DQ147648 & DQ235127 & \\
\hline M. endophytica & & CBS 111519 & DQ246255 & DQ267579 & DQ147646 & DQ235131 & \\
\hline M. endophytica & & CMW 5225 & DQ246252 & DQ267580 & DQ147649 & DQ235128 & \\
\hline M. fori & & CMW 9095 & DQ204748 & AF468869 & DQ147618 & DQ211664 & \\
\hline M. fori & & CMW 9095 & DQ204749 & DQ267581 & DQ147619 & DQ211665 & \\
\hline M. gracilis & & CBS 243.94 & DQ204750 & DQ267582 & DQ147616 & DQ211666 & \\
\hline M. grandis & & CMW 8557 & DQ246241 & DQ267583 & DQ147644 & DQ235108 & \\
\hline M. grandis & & CMW 8554 & DQ246240 & DQ267584 & DQ147643 & DQ235107 & \\
\hline M. gregaria & & CBS 110501 & DQ246251 & DQ267585 & DQ147650 & DQ235130 & \\
\hline M. intermedia & & CBS 114415 & DQ246248 & AY725547 & DQ147627 & DQ235132 & \\
\hline M. keniensis & & CMW 5147 & DQ246259 & AF309601 & DQ147611 & DQ235100 & \\
\hline M. lateralis & & CBS 110748 & DQ204768 & AF173315 & DQ147651 & DQ211684 & \\
\hline M. lateralis & & CBS 111169 & DQ246260 & AY25550 & DQ147652 & DQ235139 & \\
\hline M. madeirae & & CBS 112895 & DQ204756 & AY725553 & DQ147641 & DQ211672 & \\
\hline M. marksii & & CBS 682.95 & DQ246249 & DQ267587 & DQ147624 & DQ235133 & \\
\hline M. marksii & & CBS 110920 & DQ246250 & AF309588 & DQ147625 & DQ235134 & \\
\hline M. marksii & & CMW 5230 & DQ246246 & DQ267588 & DQ147626 & DQ235135 & \\
\hline M. nubilosa & & CBS 116005 & DQ246228 & AF309618 & DQ147666 & DQ235111 & \\
\hline M. nubilosa & & CBS 114708 & DQ246229 & AF449099 & DQ147667 & DQ235112 & \\
\hline M. parkii & & CBS 387.92 & DQ246245 & AY626979 & DQ147612 & DQ235137 & \\
\hline M. parva & & CBS116289 & DQ246243 & AY626980 & DQ147645 & DQ235110 & \\
\hline M. parva & & CBS110503 & DQ246242 & AY725576 & DQ147642 & DQ235109 & \\
\hline M. tasmaniensis & & CBS111687 & DQ246233 & DQ267591 & DQ147676 & DQ235121 & \\
\hline M. tasmaniensis & & CBS114556 & DQ246234 & DQ267592 & DQ147677 & DQ235122 & \\
\hline Annellosympodiella juniper & & CPC 23276 & KJ869204 & KJ869204 & & & MF951436 \\
\hline Australosphaerella nootherensis & $\begin{array}{l}\text { Mycosphaerella } \\
\text { nootherensis }\end{array}$ & CBS 130522 & KF901835 & MF951293 & & & \\
\hline Brunswickiella parsonsiae & & CBS 137979 & KJ869188 & KJ869131 & & & MF951593 \\
\hline Brunneosphaerella nitidae & & CBS 130595 & GU214396 & GU214625 & & & \\
\hline B. protearum & & CBS $130597^{\text {ET }}$ & GU214397 & GU214626 & & & \\
\hline Chuppomyces handelii & Mycosphaerella handelii & CBS 113302 & GU214437 & EU167581 & & & \\
\hline Cytostagonospora martiniana & Septoria sp. & CBS $135102^{\mathrm{ET}}$ & KF251657 & KF251153 & & & MF951484 \\
\hline Devonomyces endophyticus & $\begin{array}{l}\text { Phaeophleospora } \\
\text { gregaria }\end{array}$ & CBS 111167 & KF902058 & KF901711 & & & MF951588 \\
\hline D. endophyticus & $\begin{array}{l}\text { Mycosphaerella } \\
\text { endophytica }\end{array}$ & CBS 114662 & KF902060 & KF901713 & & & MF951590 \\
\hline Epicoleosporium ramularioides & & CBS 141103 & GU214688 & GU214688 & & & \\
\hline Exosporium livistonae & Passalora sp. & CBS 131313 & JQ044446 & JQ044427 & & & \\
\hline Hyalinozasmidium sideroxyli & Zasmidium sp. & CBS 142191 & MF951169 & MF951323 & & & \\
\hline Madagascaromyces intermedius & Passalora intermedia & CBS 124154 & FJ790297 & FJ790267 & & & \\
\hline Microcyclosporella mali & & CBS 126136 & GU570547 & GU570535 & & & \\
\hline Mycodiella sumatrensis & $\begin{array}{l}\text { Mycosphaerella } \\
\text { sumatrensis }\end{array}$ & CBS 118501 & JX901872 & DQ303049 & & & \\
\hline
\end{tabular}

\footnotetext{
${ }^{\mathrm{a}} \mathrm{ET}$ : ex-epitype.
} 
from the actively growing edge of 4-day-old cultures were placed at three equidistant points on a $90-\mathrm{mm}$ plate containing the respective media. The diameter of each colony was measured as described above after incubation at $25^{\circ} \mathrm{C}$ in the dark for 2 weeks. This entire experiment was replicated nine times. For enhancing the production of sexual and asexual spores, the incubation period of the cultures for all growth media was extended for 110 more days. Data related to colony diameter in each treatment were compared using Duncan multiple range tests (DMRT) $(\alpha=0.05)$ using the JMP Pro 10.0.0 software. To examine size and shape of the conidia, the following

Table 2. (Continued from previous page)

\begin{tabular}{|c|c|c|c|c|c|c|c|}
\hline \multirow[b]{2}{*}{ Current name } & \multirow{2}{*}{$\begin{array}{l}\text { Previous name } \\
\text { (if different) }\end{array}$} & \multirow[b]{2}{*}{ Isolate no. $^{\mathrm{a}}$} & \multicolumn{5}{|c|}{ GenBank accession number } \\
\hline & & & LSU & ITS & Actin & EF-1 $\alpha$ & rpb2 \\
\hline Mycosphaerelloides madeirae & Mycosphaerella madeirae & CBS 112895 & KF902017 & AY725553 & & & \\
\hline Neoceratosperma eucalypti & & CBS 142190 & KJ869210 & KJ869153 & & & \\
\hline Neomycosphaerella pseudopentameridis & & CBS 136407 & KF777226 & KF777173 & & & \\
\hline N. legnophoricola & Stenella sp. & CBS 142189 & MF951183 & MF951327 & & & \\
\hline Neopenidiella nectandrae & $\begin{array}{l}\text { Cladosporium } \\
\text { ferrugineum }\end{array}$ & CBS 734.87 & KF901982 & MF951335 & & & MF951546 \\
\hline Nothopericoniella persea-macranthae & $\begin{array}{l}\text { Periconiella persea- } \\
\text { macranthae }\end{array}$ & CBS 122282 & GU452681 & MF951355 & & & MF951584 \\
\hline Nothopericoniella persea-macranthae & $\begin{array}{l}\text { Periconiella persea- } \\
\text { macranthae }\end{array}$ & CBS 122097 & GU452682 & MF951354 & & & MF951583 \\
\hline Lecanosticta acicola & & CBS 133791 ET & КC013017 & KC012999 & & & MF951507 \\
\hline L. brevispora & & CBS 133601 & KF902021 & JX901763 & & & MF951508 \\
\hline L. longispora & & CBS $133602^{\mathrm{ET}}$ & JX901858 & JX901766 & & & MF951510 \\
\hline Pachyramichloridium pini & & CBS 461.82 & EU041859 & EU041802 & & & \\
\hline Paramycosphaerella brachystegiae & & CBS 136436 & KF777230 & KF777178 & & & \\
\hline Passalora zambiae & & CBS116289 & DQ246264 & KF901810 & DQ147675 & DQ235136 & \\
\hline P. wachendorfiae & $\begin{array}{l}\text { Mycosphaerella } \\
\text { wachendorfiae }\end{array}$ & CBS 129579 & JF951163 & JF951143 & & & \\
\hline Phaeophloeospora eugeniae & & CPC 15143 & FJ493206 & FJ493188 & & & MF951594 \\
\hline P. eugeniae & & СРC 15159 & FJ493207 & FJ493189 & & & MF951595 \\
\hline Polyphialoseptoria tabebuiae-serratifolia & & CBS 112650 & KF251716 & KF251213 & & & \\
\hline P. terminaliae & & CBS 135106 & KF251717 & KF251214 & & & \\
\hline Pseudopericoniella levispora & Periconiella levispora & CBS 873.73 & EU041837 & EU041780 & & & \\
\hline Pseudozasmidium vietnamense & $\begin{array}{l}\text { Paramycosphaerella } \\
\text { vietnamensis }\end{array}$ & CBS 119974 & JF700944 & DQ632675 & & & \\
\hline Ruptoseptoria unedonis & Ruptoseptoria unedonis & CBS 755.70 & KF251732 & KF251229 & & & \\
\hline Virosphaerella pseudomarksii & $\begin{array}{c}\text { Mycosphaerella } \\
\text { pseudomarksii }\end{array}$ & CBS 123241 & KF902127 & KF901770 & & & \\
\hline Xenomycosphaerella elongata & & CBS 120735 & JF700942 & EF394833 & & & \\
\hline Xenosonderhenia eucalypti & & CBS 138858 & КР004485 & КР004457 & & & \\
\hline Xenosonderhenioides indonesiana & Passalora sp. & CBS 142239 & MF951261 & MF951396 & & & \\
\hline Zasmidium angulare & & CBS 132094 & JQ622096 & JQ622088 & & & MF951690 \\
\hline Z. fructigenum & & CBS 13962 & KP895926 & KР896056 & & & MF951704 \\
\hline Z. nocoxi & & CBS 125009 & KF251788 & KF251284 & & & MF951719 \\
\hline Z. xenoparkii & Stenella xenoparki & CBS 111185 & JF700966 & DQ303028 & & & MF951732 \\
\hline \multicolumn{8}{|l|}{ Schizothyriaceae } \\
\hline Schizothyrium pomi & & CBS 228.57 & EF134947 & EF134947 & & & \\
\hline \multicolumn{8}{|l|}{ Dissoconiaceae } \\
\hline Ramichloridium apiculatum & Chloridium apiculatum & CBS 156.59 & EU041848 & EU041791 & & & \\
\hline Uwebraunia australiensis & Dissoconium australiensis & CBS 120729 & KF442553 & KF442513 & & & \\
\hline U. musae & Dissoconium mиsae & CBS 122453 & JQ739816 & EU514225 & & & \\
\hline \multicolumn{8}{|l|}{ Phaeothecoidiellaceae } \\
\hline Exopassalora zambiae & Passalora zambiae & CBS 112971 & EU019273 & AY725523 & & & \\
\hline Sporidesmajora pennsylvaniensis & & CPC 16112 & MF951122 & MF951287 & & & \\
\hline Houjia pomigena & & CBS 125224 & MF951120 & MF951285 & & & \\
\hline \multicolumn{8}{|l|}{ Teratosphaeriaceae } \\
\hline Acrodontium crateriforme & Chloridium crateriforme & CBS 144.33 & KX286952 & MF951410 & & & \\
\hline Batcheloromyces proteae & & CBS $110696^{\mathrm{ET}}$ & EU019247 & JF746163 & & & \\
\hline Myrtapenidiella corymbia & Penidiella corymbia & CBS 124769 & KF901838 & GQ303286 & & & \\
\hline Parapenidiella tasmaniensis & & CBS 111687 & GU214452 & KF901521 & & & \\
\hline Pseudoteratosphaeria flexuosa & Mycosphaerella flexиosa & CBS 110743 & KF902098 & DQ302955 & & & \\
\hline Readeriella nontingens & Readeriella nontingens & CPC 14444 & GQ852663 & GQ852786 & & & \\
\hline Stenella araguata & & CBS 105.75 & EU019250 & EU019250 & & & \\
\hline Teratosphaeria stellenboschiana & & CBS 125215 & KF937247 & KF901733 & & & \\
\hline \multicolumn{8}{|l|}{ Cladosporiaceae } \\
\hline Cladosporium allicinum & & CBS 188.53 & MF951115 & KT600367 & & & \\
\hline Cladosporium sp. & & CBS 179.47 & MF951118 & MF951283 & & & \\
\hline \multicolumn{8}{|l|}{ Dothioraceae } \\
\hline Cylindroseptoria ceratonia & Septoria ceratoniae & CBS 477.69 & KF251655 & KF251151 & & & MF951419 \\
\hline \multicolumn{8}{|l|}{ Botryosphaeriaceae } \\
\hline Botryosphaeria ribis & & CMW 7773 & DQ246263 & DQ267604 & DQ267605 & DQ235142 & \\
\hline
\end{tabular}


slide culture techniques were followed. A small square block $\left(1 \mathrm{~cm}^{2}\right)$ of the medium was cut from the PDA plate and placed in the middle of the slide. Using a sterilized needle, the four sides of the PDA block were inoculated with mycelium of isolate MN10. A coverslip $(18 \times$ $18 \mathrm{~mm}$ ) was placed on top of the inoculated PDA block, and then the slide was placed inside a petri dish containing moist filter paper on a glass support. After approximately 3 months of incubation at $25^{\circ} \mathrm{C}$ in the dark, the conidia formed across the underside of the coverslip, and their sizes were measured with a stage micrometer under an Olympus BX43 microscope (Olympus Corporation, Japan) at 400x magnification. To examine the size and shape of the pseudothecia, asci, and ascospores, mature pseudothecia were excised from a lesion of overwintered infected leaves, squashed in lactophenol-acid cotton blue, and examined at 400x. The size of the pseudothecia, asci, and ascospores were measured in the same way as the size of conidia was measured.

Pathogenicity and host specificity analysis. In field studies, the pathogenicity of ascospores and conidia were tested on 2-year-old seedlings of persimmon, apple, peach, cherry, and plum. Seedlings were washed with sterile distilled water. Conidial suspensions were prepared from 75- to 90-day-old cultures in distilled water. Ultrapure water was added to the petri plate containing the desired $M$. nawae culture. The culture was rubbed until the conidia loosened and became suspended in the solution. The resulting suspension was filtered through four layers of cheesecloth to remove mycelial fragments. The concentration of the conidial suspension was measured using a hemocytometer. A suspension of $1 \times 10^{4}$ conidia $/ \mathrm{ml}$ was prepared from a concentrated suspension (using the formula $\nu 1 \times c 1=\nu 2 \times c 2)$. To prepare the ascospore suspension $\left(1 \times 10^{4}\right.$ ascospores $/ \mathrm{ml}$ ), the same procedure was used. The ascospore suspension was prepared by soaking overwintered diseased leaves in ultra-pure water. Ascospore or conidial suspensions were sprayed onto seedlings of different fruits. Seedlings sprayed with distilled water were used as the negative control. Seedlings treated with conidia, or ascospores, or water were isolated separately outdoors until symptoms developed. Five seedlings were used per treatment. The inoculation of seedlings was done in mid-July. Disease incidence was estimated as the total percentage of symptomatic (having at least one circular spot) leaves per seedling, and disease severity was estimated according to Berbegal et al. (2012).

In the laboratory, ascospores and conidia were tested for pathogenicity using small branches of apple, peach, cherry, and plum. Small branches (healthy) of the respective trees were brought to the laboratory and cut into small pieces $(6-8 \mathrm{~cm}$ in length), which were disinfected through both surface and autoclave sterilization. Surface sterilization was done with $70 \%$ ethanol for $1 \mathrm{~min}$ and $1 \%$ $\mathrm{NaOCl}$ for 2 min followed by rinsing in sterile distilled water. The sterilized stems were placed in a plastic saucer and allowed to dry before inoculation. The stems were then wounded by removing a small square of tissue and placing a $10-\mu l$ droplet of conidial suspension

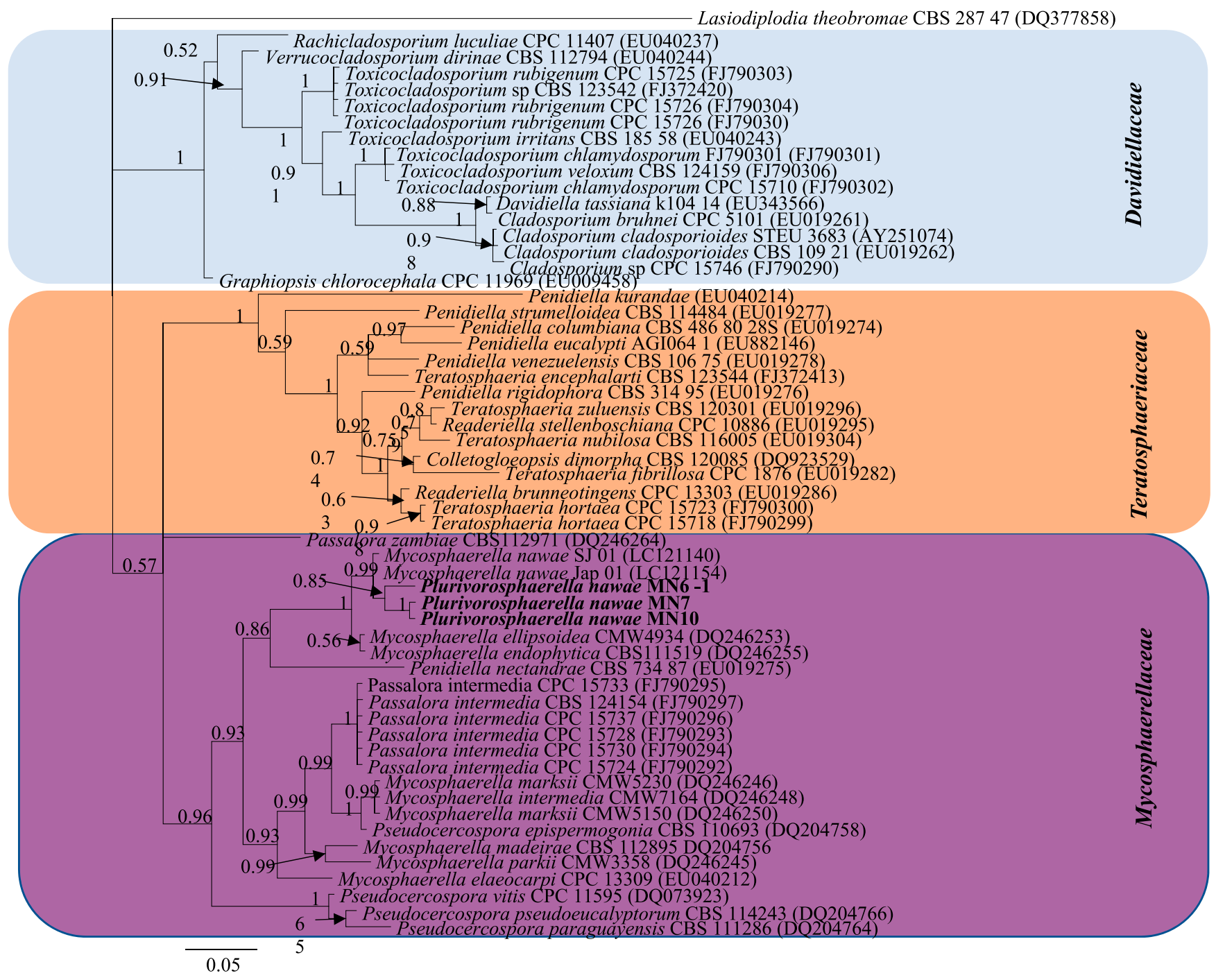

Fig. 1. Bayesian inference (BI) tree (based on $50 \%$ majority rule consensus) of the LSU sequence alignment showing phylogenetic affinities of the present isolates. The tree is rooted to Lasiodiplodia theobromae (GenBank accession DQ377858). The Bayesian inference posterior probabilities values are $>50 \%$ around the branch. The scale bar shows the number of substitutions per nucleotide position. Family clades are delimited in boxes, with the family name indicated on the right. 
over the wound. Distilled water was used as a negative control. The plastic saucers with the inoculated stems (positive and negative controls) were transferred to an enclosed sterile plastic box containing moist tissue paper. The stems were incubated at $25^{\circ} \mathrm{C}$ in high humidity to encourage disease development, and observed periodically.

Scanning electron microscopy of conidia produced on leaves. The fine fungal structures on infected leaves were observed using field emission scanning electron microscopy (JEOL FE-SEM JSM-
6701F; JEOL USA, Inc.). Samples (leaf and culture) were prepared for SEM according to Kwon et al. (1998b). The leaves of inoculated seedlings showing typical CLSP symptoms were collected at the end of October after defoliation. The lesions on infected leaves were cut into small sections $(5 \times 5 \mathrm{~mm})$ with a surgical blade and fixed in $2.5 \%$ glutaraldehyde for $24 \mathrm{~h}$. The specimens were washed with $0.1 \mathrm{M}$ phosphate buffer ( $\mathrm{pH} 7.4$ ), postfixed with $2 \%$ osmium tetroxide (Sigma-Aldrich, Korea) for $90 \mathrm{~min}$, and washed again with the same

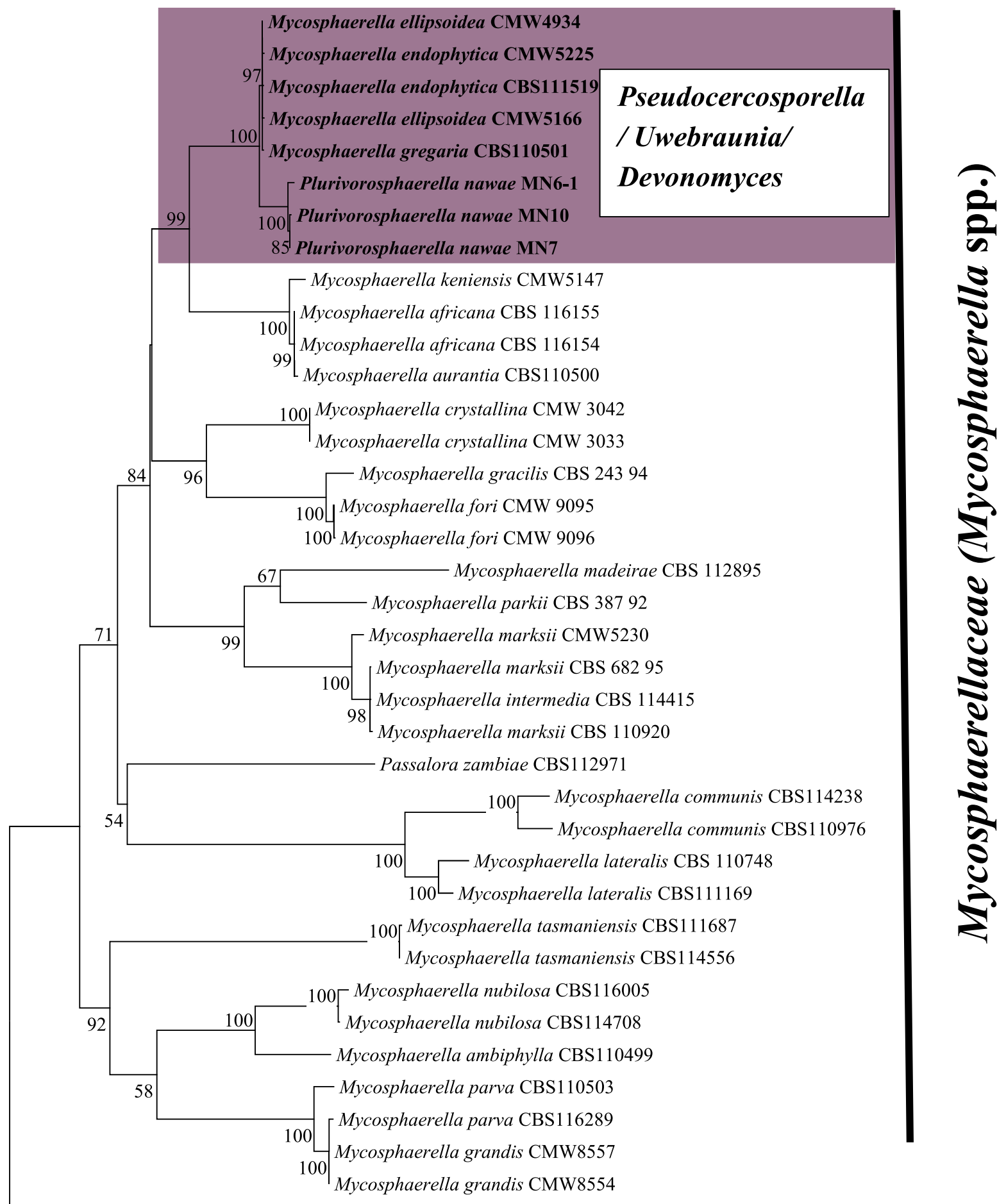

Botryosphaeria ribis CMW7773

0.05

Fig. 2. Maximum likelihood tree from MEGA 6 showing the phylogenetic relationships based on the combined ITS, LSU, ACT, and EF-1 $\alpha$ DNA sequence alignment of present isolates and Mycosphaerella spp. occurring on Eucalyptus. The scale bar shows the number of substitutions per site, and bootstrap support values (>50\%) from 1,000 replicates are shown at the nodes. 
buffer. The specimens were dehydrated in a series of ascending concentrations of ethanol $(20,40,60,80$, and $90 \%)$ for $30 \mathrm{~min}$ and $100 \%$ for $60 \mathrm{~min}$, followed by a mixture of isoamyl acetate + ethanol (1:1) for $30 \mathrm{~min}$. Specimens were then dried in a fume hood. Finally, specimens were sputter-coated with gold and observed under a JEOL FE-SEM at Central Lab of Kyungpook National University, Sangju campus, Korea.

\section{Results}

DNA amplification and identification. The complete amplification of ITS and the partial amplification of LSU, Act, rpb2, and EF$1 \alpha$ was successful for all isolates (Table 2). The sizes of the resulting sequences were: ITS $\sim 630 \mathrm{pb}, \mathrm{LSU} \sim 1,335 \mathrm{pb}$, Act $\sim 217 \mathrm{pb}, \mathrm{rpb} 2$ $\sim 993 \mathrm{pb}$, and EF-1 $\alpha \sim 317 \mathrm{pb}$. The isolates of the present study were identified as $M$. nawae based on the obtained ITS sequences. A BLAST search showed that the ITS sequences of the present isolates were $100 \%$ identical with those of the Spanish, Korean, and Japanese M. nawae isolates (GQ465767, GQ465767, LC121124, LC121127, and LC121128).

Phylogenetic analysis. Dataset 1 consisted of the alignment of the LSU loci that contained 57 taxa representing several genera known from culture belonging to Mycosphaerellaceae, Teratosphaeriaceae, and Davidiellaceae. A strain of Lasiodiplodia theobromae was used as the outgroup. The Bayesian analyses of the LSU gene alignment generated 16,562 trees, 12,423 of which were used to construct the tree and calculate the posterior probabilities (Fig. 1).

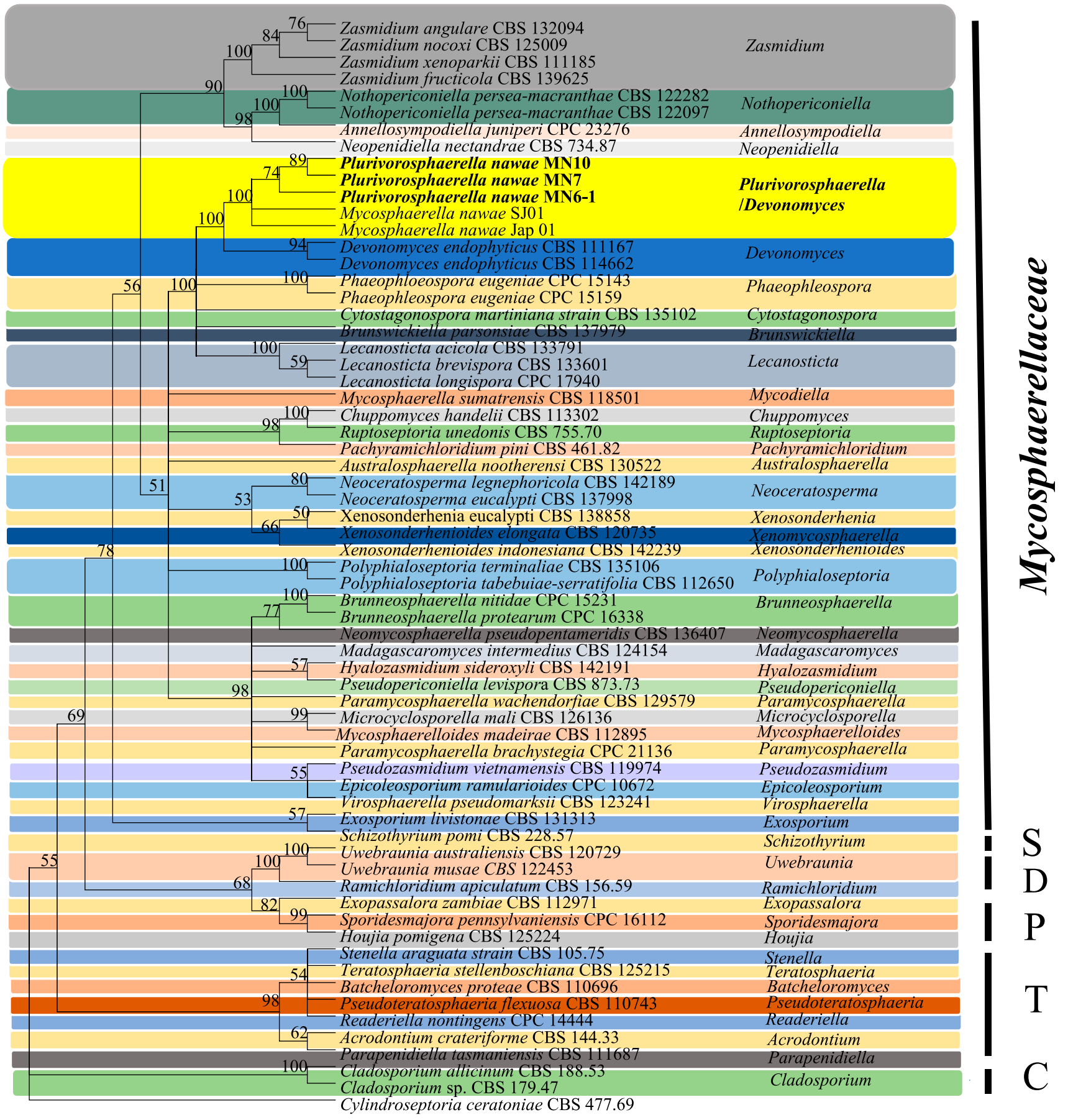

Fig. 3. Phylogenetic tree resulting from the maximum likelihood analysis of the combined LSU and ITS sequence alignment of anamorphic genera belonging to Mycosphaerellaceae, Dissoconiaceae (D), Phaeothecoidiellaceae (P), Schizothyriaceae (S), Teratosphaeriaceae (T), and Cladosporiaceae (C). The maximum likelihood bootstrap support values $(>50 \%)$ are indicated at the nodes. The clades of the genera are delimited by boxes, with the genus name indicated on the right. The tree is rooted to Cylindroseptoria ceratoniae (CBS 477.69). 
Figure 1 shows the present isolates confidently identified as a member of Mycosphaerellaceae, as they clustered together with other genera in Mycosphaerellaceae with 0.96 (96\%) bootstrap support.

Dataset 2 consisted of the alignment of four loci (ITS, LSU, Act, and $\mathrm{EF}-1 \alpha$ ) that contained 38 taxa representing several genera known from culture belonging to Mycosphaerellaceae occurring on Eucalyptus, which were described by Hunter et al. (2006). A strain of Botryosphaeria ribis was used as the outgroup. The ML analysis of the concatenated four-locus alignment reached a final ML highest $\log$ likelihood of -15859.7540 . The initial tree(s) for the heuristic search were obtained automatically by applying Neighbor-Join and BioNJ algorithms to a matrix of pairwise distances estimated using the Maximum Composite Likelihood (MCL) approach. The topology with the superior log likelihood value was then selected (Fig. 2). A discrete Gamma distribution was used to model the evolutionary rate differences among sites (five categories $(+\mathrm{G}$, parameter $=$ $0.4795)$ ). The rate variation model allowed for some sites to be evolutionarily invariable $([+\mathrm{I}], 42.3 \%$ sites $)$. The tree was drawn to scale, with branch lengths measured in the number of substitutions per site. Codon positions included were $1 \mathrm{st}+2 \mathrm{nd}+3 \mathrm{rd}+$ noncoding. There were a total of 2,580 positions in the final dataset. Figure 2 shows that the present isolates are closely related to Mycosphaerella endophytica, which is synonymous to both Devonomyces endophyticus and Pseudocercosporella endophytica (Videira et al. 2017).

Dataset 3 consisted of the alignment of two loci (ITS and LSU) that contained 65 taxa of anamorphic-typified genera belonging to Mycosphaerellaceae (related to the present isolates), Dissoconiaceae, Phaeothecoidiellaceae, Schizothyriaceae, Teratosphaeriaceae, and
Cladosporiaceae (Videira et al. 2017). A strain of Cylindroseptoria ceratoniae was used as an outgroup. The ML analysis of the concatenated two-locus alignment reached a final ML highest log likelihood of -32641.0641 . The initial tree(s) for the heuristic search were obtained automatically by applying Neighbor-Join and BioNJ algorithms to a matrix of pairwise distances estimated using the MCL approach, and the topology with the superior log likelihood value was then selected (Fig. 3). A discrete Gamma distribution was used to model the evolutionary rate differences among sites (five categories $(+\mathrm{G}$, parameter $=0.4931))$. The rate variation model allowed for some sites to be evolutionarily invariable $([+\mathrm{I}], 36 \%$ sites). The tree was drawn to scale, with branch lengths measured in the number of substitutions per site. Codon positions included were $1 \mathrm{st}+2 \mathrm{nd}+3 \mathrm{rd}+$ noncoding. The final dataset contained a total of 1,110 positions. Figure 3 demonstrates that the phylogenetic positions of M. nawae isolates are close to the genus Devonomyces. The phylogenetic position of the present isolates is outside the Phaeopleospora clade, sitting in (Fig. 3) sister position to the clade of Devonomyces.

Dataset 4 consisted of 21 taxa belonging to the genera Zasmidium, Nothopericoniella, Annellosympodiella, Neopenidiella, Devonomyces, Phaeophleospora, Cytostagonospora, Brunswickiella, and Lecanosticta (Fig. 3). Cylindroseptoria ceratoniae (CBS 477.69) was used as the outgroup. The Bayesian analyses of combined alignment, based on a total of 1,818 characteristic (ITS: 491, LSU: 557, and $\mathrm{rpb} 2$ : 770), generated 1,502 trees, 1,126 of which were used to construct the tree and to calculate the posterior probabilities (Fig. 4, first value: $\mathrm{PP} \leq 1$ shown). The ML analysis reached a final

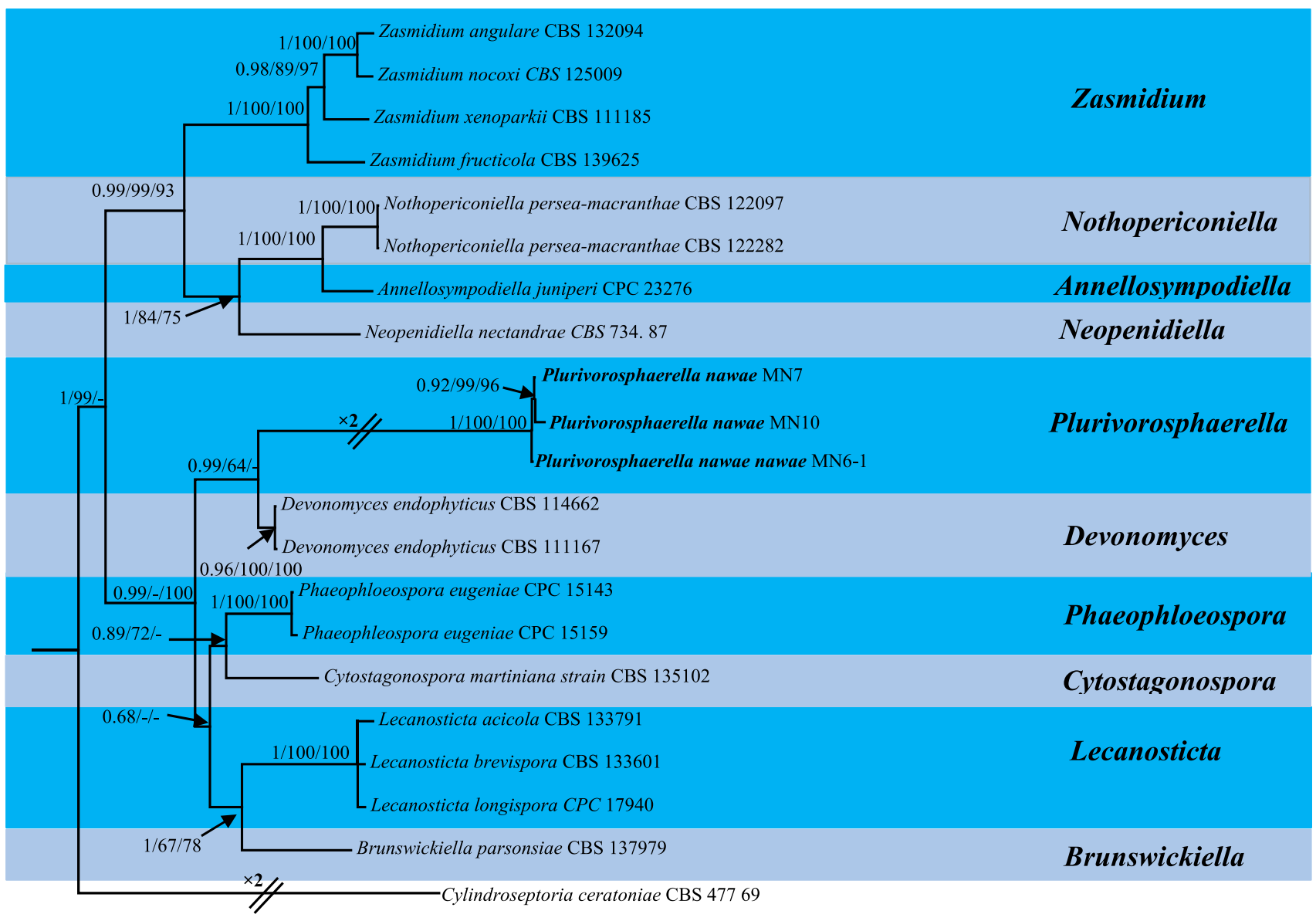

0.5

Fig. 4. Phylogenetic tree ( $50 \%$ majority rule consensus) resulting from a Bayesian analysis of the combined ITS, LSU, and rpb2 sequence alignment (dataset 4 ; representing Zasmidium, Nothopericoniella, Annellosympodiella, Neopenidiella, Mycosphaerella, Devonomyces, Phaeophleospora, Cytostagonospora, Brunswickiella, and Lecanosticta genus of Fig. 3). The Bayesian posterior probabilities (PP), maximum likelihood bootstrap support values (50\%; ML-BS), and maximum parsimony bootstrap support values (50\%; MP-BS) are given at the nodes (PP/ML-BS/MP-BS). The scale bar represents the expected number of changes per site. The tree is rooted to Cylindroseptoria ceratoniae (CBS 477.69). The lengths of two branches with $\times 2$ on them were halved for the layout of the tree. 
ML highest log likelihood of -10384.6325 . The final dataset contained a total of 1,815 positions.

The bootstrap support values from the best-scoring tree were mapped on the Bayesian tree as the second value in the tree nodes (Fig. 4; ML-BS $\geq 50 \%$ shown). The MP analysis generated the most parsimonious tree with length $=1,853, \mathrm{CI}=0.592308, \mathrm{RI}=0.759847$, and composite index $=0.477161(0.450063)$ for all sites and parsimony-informative sites (in parentheses in Figure 4). The percentage of replicate trees in which the associated taxa clustered together in the bootstrap test (1,000 replicates) was mapped on the Bayesian tree as the third value in the tree nodes (Fig. 4, MP-BS $\geq 50 \%$ shown). Figure 4 shows that the isolates of this study are sitting in a sister clade to Devonomyces but outside of Phaeopleospora clade.

Morphological analysis. Teleomorph. Pseudothecia were observed in the lesions on the undersides of the diseased leaves. Pseudothecia matured in spring (late April) after overwintering and were scattered over lesions. Microscopic analyses revealed the following morphological characteristics: Pseudothecia black, oval, flask- and pear-shaped, 57.17-131.32 × 55.35-116.74 $\mu \mathrm{m}$ (average $81.23 \times$ $74.30 \mu \mathrm{m})(n=50)$ (Fig. 5A, B) with $\sim 35$ asci per pseudothecia. Asci 30.70-51.42 × 8.11-10.4 $\mu \mathrm{m}$ (average, $40.65 \times 9.00 \mu \mathrm{m})(n=50)$, banana-shaped and 8-spored (Fig. 5B). Ascospores spindle-shaped, uniseptate (unequally), hyaline, 10.56-13.41 × 2.93-4.65 $\mu \mathrm{m}$ (average, $12.08 \times 3.85 \mu \mathrm{m})(n=50)($ Fig. $5 \mathrm{D}, \mathrm{E})$. During the germination of ascospores, germ tubes emerged from one end or both ends (Fig. $5 \mathrm{~F}, \mathrm{G})$. Ascospores became slightly swollen or completely distorted after several germ tubes emerged, growing at various angles to the long axis of the spore (Fig. 5F, G). Germ tubes hyaline (Fig. 5F, G).

Anamorph. The cultures grew slowly and reached a diameter of 11-13 mm within 2 weeks on PDA at $25^{\circ} \mathrm{C}$ in the dark. The colonies were initially dark green and ultimately became dark gray to black on PDA while in incubation at $25^{\circ} \mathrm{C}$ in the dark. When incubated at $5^{\circ} \mathrm{C}$ in the dark, the colonies were slightly pinkish in color. In the presence of light or high $\mathrm{RH}$, the growth of mycelium was significantly faster than that of mycelium incubated in the dark at $20^{\circ} \mathrm{C}$ and $25^{\circ} \mathrm{C}$. In all conditions, the growth of mycelium was significantly less at $5^{\circ} \mathrm{C}$ and $10^{\circ} \mathrm{C}$. Mycelial growth at $15^{\circ} \mathrm{C}$ was significantly faster than that at $5^{\circ} \mathrm{C}$ and $10^{\circ} \mathrm{C}$ but less than that at $20^{\circ} \mathrm{C}$ and $25^{\circ} \mathrm{C}$. There was no difference in mycelial growth at $20^{\circ} \mathrm{C}$ and $25^{\circ} \mathrm{C}$ in dark. The effect of culture media on mycelial growth was significant. The cultures grew significantly larger on OMA than on PDA and MA. The least mycelium growth was observed on LCA. Pseudothecial and conidial formation was observed only on OMA and PDA after 120 days of incubation at $25^{\circ} \mathrm{C}$ in light and high RH. The pseudothecia on OMA were small, black, and spherical or oval (Fig. 6A). The mycelium was dark gray, composed of septate, guttulate hyphae, width on average $\pm \mathrm{SD}=4.20 \pm 0.46(n=50)$ (Fig. $6 \mathrm{~B}, \mathrm{C})$. The pseudothecia formed through the aggregation and pigmentation of mycelium (Fig. 6D, E). Two types of conidia were observed: conidia of type I: Conidia formed singly or in chains, single-celled or septate (0-1), and variously shaped (cylindrical, oval, obovoid), guttulate, 9.3-28.2 × 4.3-11.7 $\mu \mathrm{m}$ (average $16.5 \times 8.1 \mu \mathrm{m})(n=50)$ in size, and light brown (Fig. 6F); and conidia of type II (rare): 3- to 6-celled, brown in color, walls slightly thickened, guttulate, constricted at the septa, and with swollen cells at the base (Fig. 6G-K). Conidiogenesis cells monoblastic or holoblastic, hila and conidiogenous loci inconspicuous, not thickened and not darkened. Conidiophores mostly reduced to conidiogenous cells, or some erect, light brown, size 17$44.86 \times 3.09-7.6 \mu \mathrm{m}$ (average, $25.16 \times 5.3 \mu \mathrm{m})(n=20)$. Conidiogenous cells integrated, terminal and lateral, forming a subcylindrical chain, the walls slightly thickened, straight to variously curved, septate and light to dark brown (Fig. 6L). Conidia germinated to form branches of mycelium (Fig. 6M, N).

Pathogenicity and host specificity analysis. The CLSP symptoms were observed on persimmon seedlings after approximately 2 months ( $>50$ days) of artificial inoculation with conidia and ascospores. The resulting symptoms from spraying the conidial suspension were identical to the typical symptoms caused by both natural and artificial ascospore infection. Disease incidence and disease severity after inoculation with conidia were $53.48 \%$ and $24.81 \%$, respectively (Table 3 ). Disease incidence and severity after inoculation with ascospores was $87.23 \%$ and $65.23 \%$, respectively (Table 3 ). No visual symptoms were observed on apple, peach, cherry, or plum seedlings inoculated with conidia or ascospores. In the laboratory experiment, $M$. nawae ( $P$. nawae comb. nov.) was able to grow superficially on the stems of apple, peach, cherry, and plum. Extent of colonization was higher in peach stems followed by apple, pine, and plum. The mycelium grew beyond the wound site. Necrosis on these hosts did not occur.
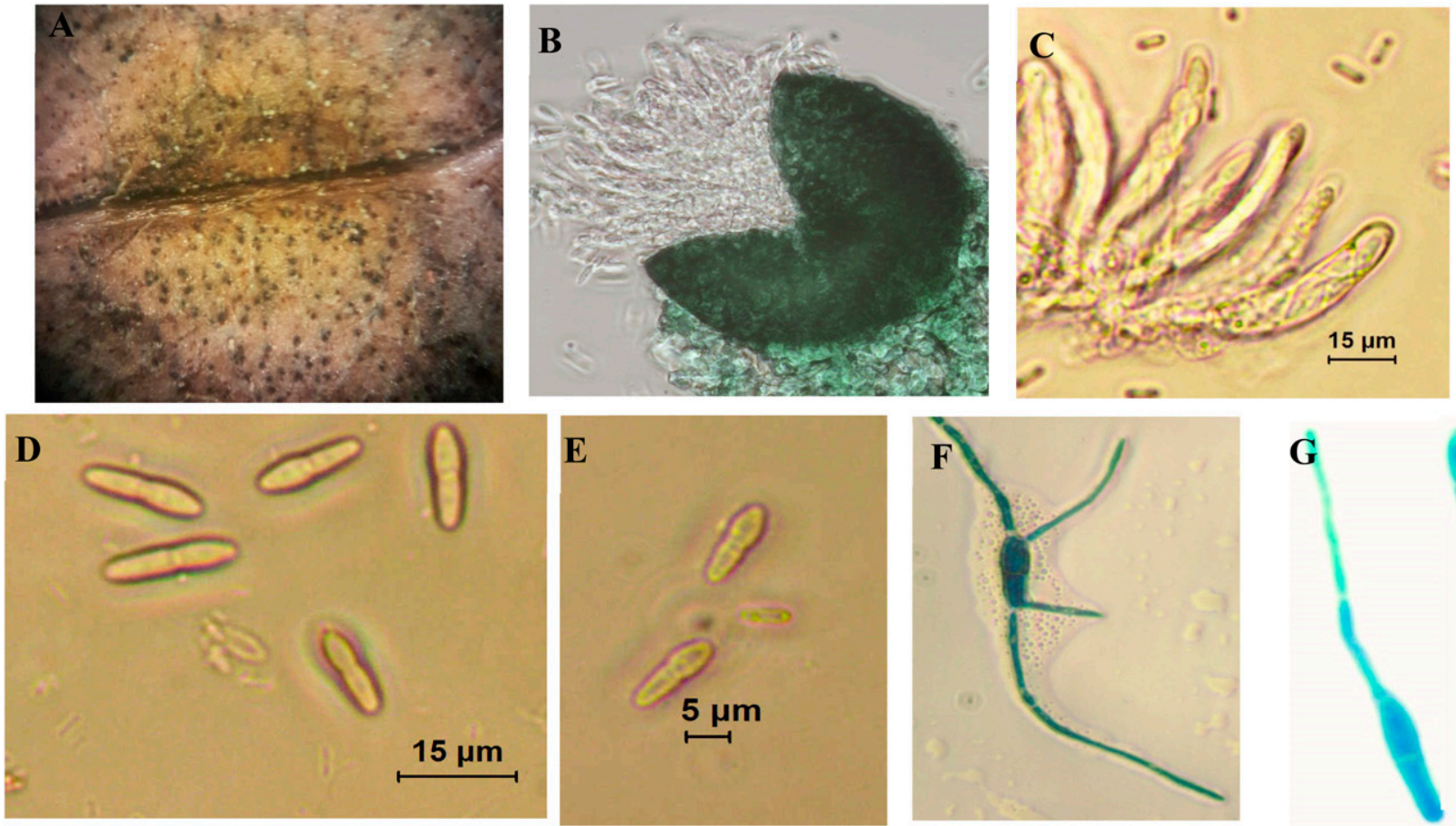

Fig. 5. Observed teleomorphic characteristics of Plurivorosphaerella nawae comb. nov. (Mycosphaerella nawae) in overwintered, infected leaves. A, Leaf spot with black pseudothecia; B, mature pseudothecia and asci; C, asci and ascospores; D-E, ascospores; and F-G, germinating ascospores (scale bars: $\mathbf{C}-\mathrm{D}=15 \mu \mathrm{m}, \mathbf{E}=5 \mu \mathrm{m}$ ). 
Electron scanning microscopy of conidia produced on leaves. Conidia and conidial chains were observed on the lesions of leaves inoculated with both conidia and ascospores under FE-SEM. The conidia and conidial chains were identical to those found in culture media (PDA and OMA) (Fig. 7A-C).

Taxonomy. Plurivorosphaerella $\mathrm{O}$. Hassan \& T. Chang, gen. nov. MycoBank, MB825548.

Etymology. The generic name Plurivorosphaerella composed of plurivorus (plurivorous) and sphaerella (from Mycosphaerella), referring to the wider host range of the type species.

Diagnosis. Phylogenetically closely allied to Devonomyces but forming a separate clade in sister position. The anamorph was different from the closely related species (Table 4), dematiaceous, conidiogenous cells producing chains of spores and catenate (true chain) dimorphic conidia, either 0-1-septate (amero- to didymosporous) or 3- to 6-celled (phrago- to scolecosporous), constricted at the septa, and with swollen cells at the base, conidiogenesis holoblastic (monoblastic or polyblastic), conidogenous loci neither thickened nor darkened-refractive, rather inconspicuous. Sexual morph mycosphaerella-like (pseudothecia flask- to pear-shaped, asci banana-shaped, with eight colorless unequally uniseptate ascospores, germinating from one or both ends).

Type species. Plurivorosphaerella nawae (Hiura \& Ikata) O. Hassan \& T. Chang, comb. nov. MycoBank, MB825619.

Basionym. Mycosphaerella nawae Hiura \& Ikata, Research Bulletin of the Faculty of Agriculture, Gifu University 5: 1, 1929.

\section{Discussion}

The genus Mycosphaerella is one of most important genera among mycologists and plant pathologists for their diverse morphological characteristics and destructive effects on crops. Although this genus has a long taxonomic history researched over many decades and
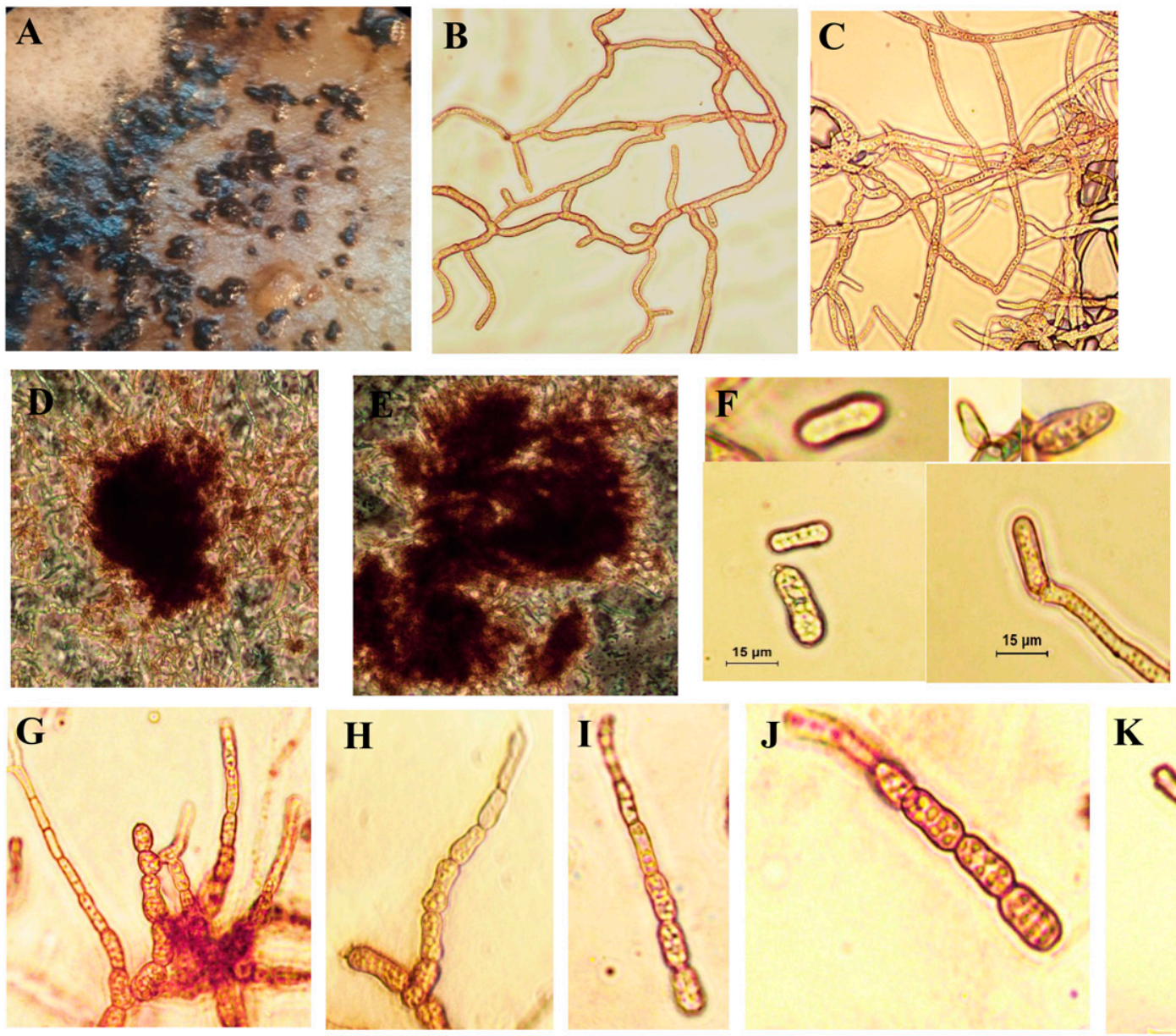

K
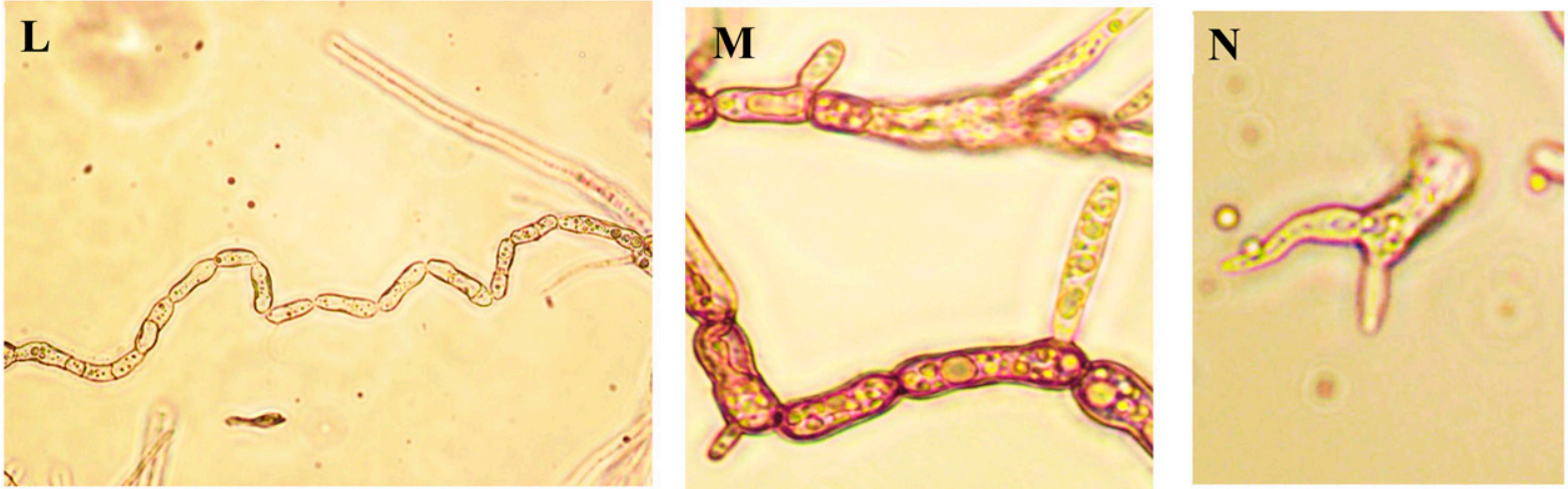

Fig. 6. Micrograph of the Plurivorosphaerella nawae comb. nov. (Mycosphaerella nawae) grown on PDA and diseased leaves. A, Pseudothecia in 120-day-old culture on Oatmeal Agar (OA); B, young mycelium (7-days-old); and C, old mycelium (>40-days-old); D-E, pseudothecia in culture; F, conidia type I, single and varying size and shape; G-J, conidia type II, constricted at the septa and swollen cells at the base; $\mathbf{K}$, conidiophore and conidia type II collected from a diseased leaf; L, conidiogenous cell which give rise to the conidia; and $\mathbf{M}-\mathbf{N}$, germinating conidia (scale bars: $\mathbf{G}=15 \mu \mathrm{m}$ ). 
published in numerous publications, major taxonomic challenges remain unresolved (Crous 2009). Recently, Videira et al. (2017) provided a phylogenetic framework for the taxonomic work within Mycosphaerella as a genus within the family Mycosphaerellaceae. It opened the door to resolving the phylogenetic position of many Mycosphaerella species, such as M. nawae. M. nawae was first identified based on morphological characteristics (Ikata and Hitomi 1929). In 1998, the anamorph of M. nawae was reported as being similar to Ramularia sp. based on morphological characteristics, and it was shown to be able to induce CLSP (Kwon et al. 1998a, b). The traditional identification (which relies on morphological characteristics) of fungal species within the Mycosphaerella complex is not reliable because many species are morphologically indistinguishable from one another (Groenewald et al. 2005; Crous 2009). Phylogenetic and genomics studies based on DNA sequence data became indispensable among mycologists owing to the accuracy of identification. Phylogenetic analyses using multigene sequence data revealed that Mycosphaerella was polyphyletic and that previously well-defined anamorph-typified genera clustered in several clades (Crous et al. 2006, 2007a, b; Hunter et al. 2006;

Table 3. Disease incidence and disease severity of Plurivorosphaerella nawae comb. nov. (Mycosphaerella nawae) species inoculated with ascospores and conidia in the seedlings of different fruits

\begin{tabular}{|c|c|c|c|c|c|c|c|c|}
\hline \multirow[b]{2}{*}{ Types of inoculum } & \multicolumn{4}{|c|}{ Disease incidence } & \multicolumn{4}{|c|}{ Disease severity } \\
\hline & Persimmon & Apple & Pears & Peach & Persimmon & Apple & Pears & Peach \\
\hline Ascospores & $87.23 \%$ & - & - & - & $65.23 \%$ & - & - & - \\
\hline Conidia & $53.48 \%$ & - & - & - & $24.81 \%$ & - & - & - \\
\hline
\end{tabular}
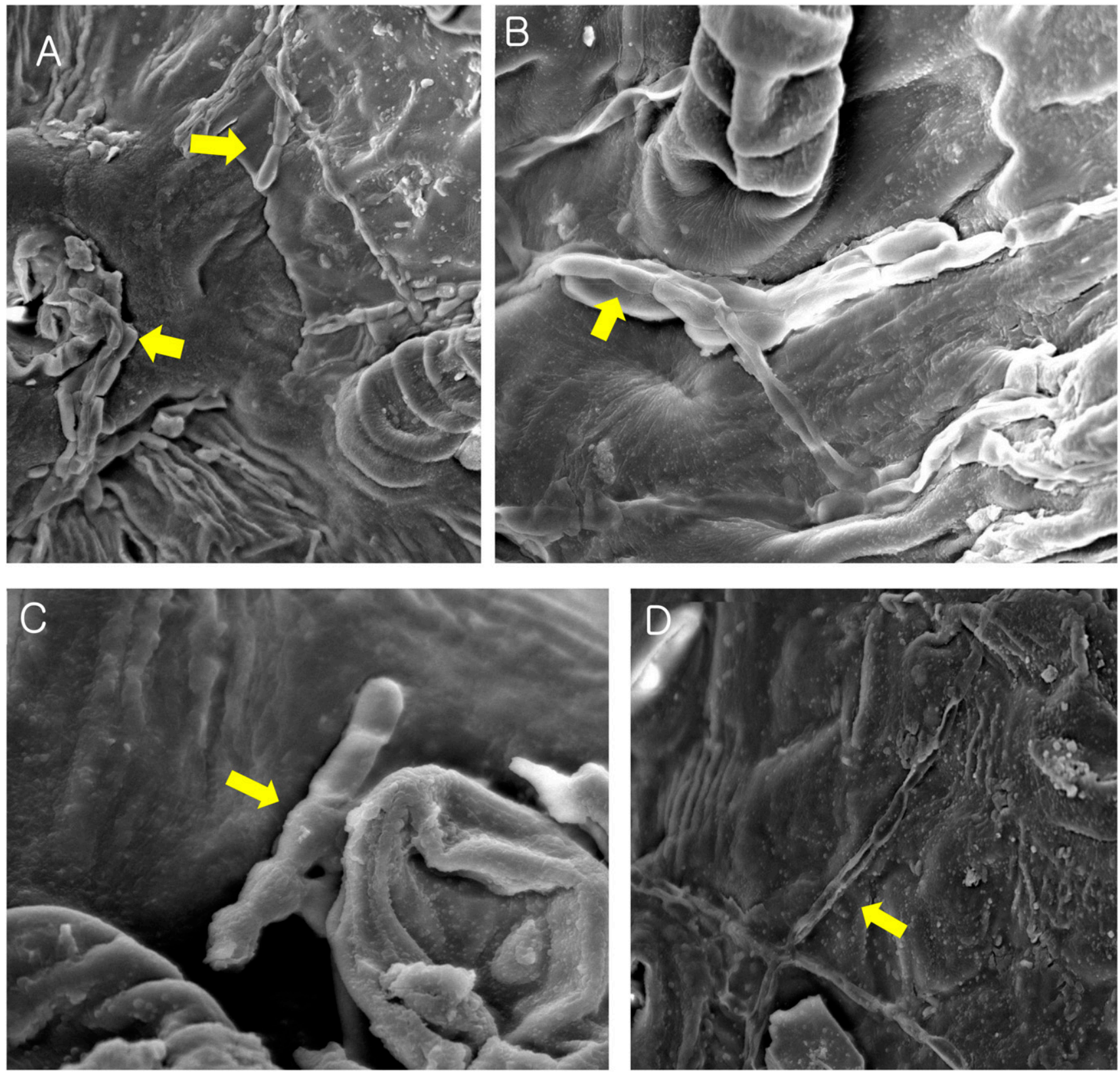

Fig. 7. Conidia observed using SEM. A-B, Conidia on leaf lesion inoculated with the conidial suspension; C-D, conidia on leaf lesion inoculated with the naturally released ascospores. 
Videira et al. 2017). Lee et al. (2016) attempted to delineate the phylogenetic position of $M$. nawae using multigene sequence data and morphological characteristics. They suggested a close affinity of $M$. nawae to the genus Phaeophleospora, despite clustering in distinct clades. However, the reported morphological data, especially for the anamorph, do not support a close affinity to Phaeophleospora. The genus Phaeophleospora seems to be polyphyletic according to phylogenetic data presented by Crous et al. (2009a). Some previously known Phaeophleospora spp. were renamed and classified as new genera, e.g., Brunswickiella (Videira et al. 2017). Hence, the phylogenetic position of $M$. nawae must be viewed with some circumspection. For this reason, the present study aimed to clarify the phylogenetic positioning of $M$. nawae. The present study integrated anamorph and teleomorph morphologies, pathogenicity, and host specificity with four phylogenetic datasets based on partial sequences of the ITS, LSU, ACT, rpb2, and EF-1 $\alpha$ gene sequence data. Based on the ITS, LSU, ACT, and EF-1 $\alpha$ sequence data presented here, it is clear that M. nawae belongs to the family Mycosphaerellaceae (Fig. 1; Fig. 2). ITS and LSU sequences retrieved from identified M. nawae isolates formed a distinct clade with Devonomyces in sister position (Fig. 3), which was confirmed by phylogenetic analysis with ITS, LSU, and rpb2 sequence data (Fig. 4). ITS has been extensively used as a molecular marker for the successful identification and subgeneric phylogenetic inference of fungi, and it was formally proposed as the primary barcode marker for fungi (Nilsson et al. 2008; Schoch et al. 2012; Videira et al. 2017). As with Colletotrichum spp., distinguishing between closely related Mycosphaerella species based on ITS sequence data is not reliable (Stielow et al. 2015; Weir et al. 2012). The combination of multilocus sequence data is not only reliable for the recognition of fungal species, but it is also fast, relatively cost-effective, and does not require specific morphological characteristics associated with life stages (Quaedvlieg et al. 2012). For this reason, a combination of ITS and a secondary barcode (LSU and rpb2) has been proposed for the recognition of many genera in Mycosphaerellaceae (Videira et al. 2017). We also found that LSU and rpb2 loci, in addition to the ITS sequence data, are sufficient for confirming the phylogenetic position of $M$. nawae. Using rpb2 gene sequence data has some benefits over the use of other genes, in that it: i) resolves higher levels of classification; ii) is easy to align, as the sequence has no introns; and iii) has a higher level of variability within sequence data, which helps to discriminate at the species level (Videira et al. 2017). However, it is difficult to amplify rpb2 (Videira et al. 2017). The difficulty regarding less available rpb2 sequence data in the public databases is overcome with the increasing amount of newly generated sequence data (Videira et al. 2017).
In this study, the $M$. nawae isolates were described by multilocus phylogenetic analysis and morphological characteristics. The comparison among the morphological characteristics of the present isolates and previously described $M$. nawae isolates has been presented in Table 4. The sexual and anamorph of the present $M$. nawae isolate was well-supported with those described by Kwon et al. (1998a, b). The conidia of the present isolate were smaller than those of the reference $M$. nawae. Conidia of the preset isolate were light brown while conidia of the reference isolate were colorless to light olive. The slight morphological differences can be explained by the influence of different growing conditions and different geographic isolates. The anamorph of the present $M$. nawae was further confirmed through FE-SEM using leaves artificially inoculated with both ascospores and conidia. Conidial chain and conidia of type II were observed from the lesions of infected leaves, which were identical with those of found in culture media. To our knowledge, we have described the germination pattern of ascospores and conidia of type II for the first time. The morphological characteristics of M. nawae are not similar to those of the genera Phaeophleospora and Devonomyces. Fungal species within Phaeophleospora are morphologically characterized by comparing them with the species P. eugeniae (Quaedvlieg et al. 2014). The conidia of P. eugeniae are characterized as being predominantly sigmoid (Crous et al. 1997). However, the recently described conidia of type II of $M$. nawae are characterized by being phragmo- to scolecosporous, while conidia of type I are aseptate or septate and vary in shape and size. The anamorph of M. nawae is similar to that of most Phaeophleospora species, such as $P$. destructans, (Burgess et al. 2006), $P$. faureae (Taylor and Crous 1999), P. stonei (Crous et al. 2009b), and $P$. vochysiae (Savi et al. 2018), but the morphology of $M$. nawae does not correspond to that of any described Phaeophleospora species. Phaeophleospora species are readily distinguishable from the anamorph of $M$. nawae by having vermiform, long obclavate, bases truncate, widest in the middle region, versicolored (basal cell lightbrown, apical cell pale brown), vermiform conidia (Andjic et al. 2007; Crous et al. 1997). The morphological characteristics of M. nawae are also comparable with those of the genus Devonomyces, as described by Videira et al. (2017). The pseudocercosporella-like morph of Devonomyces endophyticus is the important morphological feature, which is distinct from the anamorph of $M$. nawae (Videira et al. 2017). Ascospores of Devonomyces are fusoid-ellipsoidal medianly 1-septate (Videira et al. 2017), while ascospore of $M$. nawae are spindle shaped and unequally 1 -septate.

M. nawae isolates used in the present study are morphologically and molecularly clearly distinct from both Phaeophleospora and Devonomyces and must therefore be accommodated in a different

Table 4. Comparison of asexual morph of the present isolates (Plurivorosphaerella nawae comb. nov.) and previously described strains of Mycosphaerella nawae and closest species of Devonomyces and Phaeophleospora as reported in the literature

\begin{tabular}{|c|c|c|c|c|}
\hline $\begin{array}{l}\text { Morphological } \\
\text { characteristics }\end{array}$ & $\begin{array}{l}\text { P. nawae comb. nov. } \\
\text { (M. nawae) (present isolates) }\end{array}$ & $\begin{array}{c}\text { M. nawae (Kwon et al. } \\
1998 \mathrm{a}, \mathrm{b})\end{array}$ & $\begin{array}{l}\text { Phaeophleospora eugeniae } \\
\text { (Crous et al. 1997) }\end{array}$ & $\begin{array}{l}\text { Devonomyces endophyticus } \\
\text { (Videira et al. 2017) }\end{array}$ \\
\hline Conidiophore & $\begin{array}{l}\text { Mostly reduced to conidiogenous } \\
\text { cells, or some erect, light brown, } \\
17-44.86 \times 3.09-7.6 \mu \mathrm{m} \\
\text { (average, } 25.16 \times 5.3 \mu \mathrm{m} \text { ), } \\
\text { aseptate }\end{array}$ & $\begin{array}{l}\text { Erect, short, colorless or } \\
\text { light brown, 20.4-102.0 } \\
\times 3.1-10.2 \mu \mathrm{m} \text { (average, } \\
49.2 \times 5.1 \mu \mathrm{m}), 0-1 \\
\text { septate (mostly aseptate) }\end{array}$ & $\begin{array}{l}\text { Absent or reduced to } \\
\text { conidiogenous cells }\end{array}$ & $\begin{array}{l}\text { Cylindrical, straight to } \\
\text { irregularly curved, rarely } \\
\text { pigmented and verruculose } \\
\text { in lower part, mostly hyaline } \\
\text { and smooth throughout, } \\
\text { thick-walled, septate }\end{array}$ \\
\hline Conidiogenous cell & $\begin{array}{l}\text { Integrated, terminal and lateral, } \\
\text { light to dark brown, forming a } \\
\text { subcylindrical chain, straight to } \\
\text { variously curved, septate }\end{array}$ & $\begin{array}{l}\text { Integrated, thickened } \\
\text { walled, brown }\end{array}$ & $\begin{array}{l}\text { Terminal, discrete, light brown, } \\
\text { subcylindrical to ampulliform, } \\
\text { percurrent }\end{array}$ & $\begin{array}{l}\text { Terminal, hyaline, smooth, } \\
\text { unbranched, straight or } \\
\text { slightly curved }\end{array}$ \\
\hline Conidia & $\begin{array}{l}\text { Conidia of type I: solitary or in } \\
\text { chain, light brown, various } \\
\text { shaped (cylindrical obovoid), } \\
\text { guttulate } 9.3-28.2 \times \\
4.3-11.7 \mu \mathrm{m} \text { (average, } 16.52 \times \\
8.1 \mu \mathrm{m}), 0-1 \text { septate. Conidia of } \\
\text { type II: } 3 \text { - to 6-celled, brown in } \\
\text { color (uniformly), constricted at } \\
\text { the septa, and with swollen cells } \\
\text { at the base }\end{array}$ & $\begin{array}{l}\text { Conidia of type I: solitary } \\
\text { or in chain, colorless to } \\
\text { light brown, various } \\
\text { shaped (cylindrical } \\
\text { obovoid), } 12.2-32.6 \times \\
6.1-10.2 \mu \mathrm{m} \text { (average, } \\
21.0 \times 9.4 \mu \mathrm{m}), 0-3 \\
\text { septate Conidia of type } \\
\text { II: Not reported }\end{array}$ & $\begin{array}{l}\text { Single type of conidia, solitary, } \\
\text { pale brown to pale olivaceous } \\
\text { brown, darker in the center and } \\
\text { paler toward both ends, } \\
\text { vermiform, long-obconical, } \\
30-150 \times 5-8 \mu \mathrm{m} \text {, (16-) } 24-27 \\
(-30) \text { euseptate, generally not } \\
\text { constricted at septa, bases } \\
\text { truncate with frills }\end{array}$ & $\begin{array}{l}\text { Single type of conidia, } \\
\text { solitary, hyaline, smooth, } \\
\text { narrowly obclavate, septate, } \\
\text { irregularly curved, rarely } \\
\text { straight, apex obtuse, base } \\
\text { long obconic-truncate, } \\
\text { lateral branches common, } \\
\text { secondary conidia forming } \\
\text { on most mature primary } \\
\text { conidia }\end{array}$ \\
\hline
\end{tabular}


genus within Mycosphaerellaceae. A previous study reported that $M$. nawae is phylogenetically distinct from Ramularia spp. (Lee et al. 2016). Ramularia species are readily distinguishable from the anamorph of $M$. nawae by having conspicuous conidiogenous loci and conidial hila, thickened and darkened-refractive, with coronate, cladosporium-like structure (Braun 1998; Videira et al. 2016). Furthermore, Ramularia species are colorless (mucedinaceous), whereas the anamorph of $M$. nawae is characterized by being pigmented (dematiaceous).

We also found that M. nawae is responsible for CLSP on persimmon. Wounded, inoculated excised stems of apple, peach, cherry, and plum did not become infected, but growth occurred on top of the wood and beyond the wounded region of each stem. M. nawae was recently isolated from the leaves of the traditional Chinese medicinal plant Smilax china as an endophyte (Wang et al. 2017). The colonization of $M$. nawae of plants other than persimmon is due to the endophytic or opportunistic nature of $M$. nawae. Some fungal species such as Colletotrichum salicis are pathogenic on one host and can opportunistically colonized another host (Johnston 2000; Weir et al. 2012). The ecology and hosts of M. nawae should be further investigated.

In conclusion, it can be said that $M$. nawae represents a new holomorphic genus within Mycosphaerellaceae, introduced in the present paper as Plurivorosphaerella, and it appears to have a restricted host range.

\section{Acknowledgments}

We would like to thank the reviewers for their valuable comments and recommendations.

\section{Literature Cited}

Andjic, V., Barber, P. A., Carnegie, A. J., Hardy, G. S., Wingfield, M. J., and Burgess, T. I. 2007. Phylogenetic reassessment supports accommodation of Phaeophleospora and Colletogloeopsis from eucalypts in Kirramyces. Mycol. Res. 111:1184-1198.

Bassimba, D. D. M., Mira, J. L., Sedano, M. E., and Vicent, A. 2017. Control and yield loss modelling of circular leaf spot of persimmon caused by Mycosphaerella nawae. Ann. Appl. Biol. 170:391-404.

Berbegal, M., Armengol, A., and García-Jiménez, J. 2012. Evaluation of fungicides to control circular leaf spot of persimmon caused by Mycosphaerella nawae. Crop Prot. 30:1461-1468.

Berbegal, M., Mora-Sala, B., and García-Jiménez, J. 2013. A nested-polymerase chain reaction protocol for the detection of Mycosphaerella nawae in persimmon. Eur. J. Plant Pathol. 137:273-281.

Berbegal, M., Pérez-Sierra, A., Armengol, J., Park, C. S., and García-Jiménez, J. 2010. First report of circular leaf spot of persimmon caused by Mycosphaerella nawae in Spain. Plant Dis. 94:374.

Braun, U. 1998. A monograph of Cercosporella, Ramularia and allied genera (phytopathogenic hyphomycetes), Vol. 2. IHW-Verlag, Eching, Germany.

Burgess, T. I., Andjic, V., Hardy, G. E. S. J., Dell, B., and Xu, D. 2006. First report of Phaeophleospora destructans in China. J. Trop. For. Sci. 18: 144-146.

Burgess, T. I., Barber, P. A., Sufaati, S., Xu, D., Hardy, G. E. StJ., and Dell, B. 2007. Mycosphaerella spp. on Eucalyptus in Asia; new species, new hosts and new records. Fungal Divers. 24:135-157.

Carbone, I., and Kohn, L. M. 1999. A method for designing primer sets for speciation studies in filamentous ascomycetes. Mycologia 91:553-556.

Cortinas, M. N., Crous, P. W., Wingfield, B. D., and Wingfield, M. J. 2006. Multigene phylogenies and phenotypic characters distinguish two species within the Colletogloeopsis zuluensis complex associated with Eucalyptus stem cankers. Stud. Mycol. 55:133-146.

Crous, P. W. 2009. Taxonomy and phylogeny of the genus Mycosphaerella and its anamorphs. Fungal Divers. 38:1-24.

Crous, P. W., and Braun, U. 2003. Mycosphaerella and its anamorphs. 1. Names published in Cercospora and Passalora. CBS Biodiversity Series 1:1-571.

Crous, P. W., Braun, U., and Groenewald, J. Z. 2007a. Mycosphaerella is polyphyletic. Stud. Mycol. 58:1-32.

Crous, P. W., Braun, U., Schubert, K., and Groenewald, J. Z. 2007b. Delimiting Cladosporium from morphologically similar genera. Stud. Mycol. 58:33-56.

Crous, P. W., Ferreira, F. A., and Sutton, B. C. 1997. A comparison of the fungal genera Phaeophleospora and Kirramyces (coelomycetes). S. Afr. J. Bot. 63: 111-115

Crous, P. W., and Groenewald, J. Z. 2005. Hosts, species and genotypes: Opinions versus data. Australas. Plant Pathol. 34:463-470.

Crous, P. W., Groenewald, J. Z., Summerell, B. A., Wingfield, B. D., and Wingfield, M. J. 2009a. Co-occurring species of Teratosphaeria on Eucalyptus. Persoonia 22:38-48.
Crous, P. W., Kang, J. C., and Braun, U. 2001. A phylogenetic redefinition of anamorph genera in Mycosphaerella based on ITS rDNA sequence and morphology. Mycologia 93:1081-1101.

Crous, P. W., Summerell, B. A., Carnegie, A. J., Wingfield, M. J., and Groenewald, J. Z. 2009b. Novel species of Mycosphaerellaceae and Teratosphaeriaceae. Persoonia 23:119-146.

Crous, P. W., Summerell, B. A., Carnegie, A. J., Wingfield, M. J., Hunter, G. C., Burgess, T. I., Andjic, V., Barber, P. A., and Groenewald, J. Z. 2009c. Unravelling Mycosphaerella: Do you believe in genera? Persoonia 23:99-118.

Crous, P. W., Wingfield, M. J., and Groenewald, J. Z. 2009d. Niche sharing reflects a poorly understood biodiversity phenomenon. Persoonia 22:83-94.

Crous, P. W., Wingfield, M. J., Mansilla, J. P., Alfenas, A. C., and Groenewald, J. Z. 2006. Phylogenetic reassessment of Mycosphaerella spp. and their anamorphs occurring on Eucalyptus. II. Stud. Mycol. 55:99-131.

Groenewald, M., Groenewald, J. Z., and Crous, P. W. 2005. Distinct species exist within the Cercospora apii morphotype. Phytopathology 95:951-959.

Hunter, G. C., Wingfield, B. D., Crous, P. W., and Wingfield, M. J. 2006. A multigene phylogeny for species of Mycosphaerella occurring on Eucalyptus leaves. Stud. Mycol. 55:147-161.

Ikata, S., and Hitomi, T. 1929. Studies on circular leaf spot of persimmon caused by Mycosphaerella nawae. Spec. Bull. Okayama Pref. Agric. Exp. Stn. 33:1-36 (in Japanese).

Jacobs, A., Truter, M., and Schoeman, M. H. 2014. Characterisation of Mycosphaerella species associated with pink spot on guava in South Africa S. Afr. J. Sci. 110:1-6.

Johnston, P. R. 2000. The importance of phylogeny in understanding hos relationships within Colletotrichum. Pages 21-28 in: Colletotrichum: Host specificity, pathogenicity, and host pathogen interactions. D. Prusky, M. B. Dickman, and S Freeman, eds. American Phytopathological Society, St Paul, MN.

Kwon, J. H., Kang, S. W., Park, C. S., and Kim, H. K. 1998a. Further evidence that Ramularia-type conidia in vivo plays a role as a secondary inoculum of Mycosphaerella nawae. Korean J. Plant Pathol. 14:393-396.

Kwon, J. H., Kang, S. W., Park, C. S., and Kim, H. K. 1998b. Identification of the imperfect stage of Mycosphaerella nawae causing circular leaf spot of persimmon in Korea. Korean J. Plant Pathol. 14:397-401.

Kwon, J. H., Kang, S. W., Park, C. S., and Kim, H. K. 1998c. Microscopic observation of the pseudothecial development of Mycosphaerella nawae on persimmon leaves infected by ascospore and conidia. Korean J. Plant Pathol. 14:408-412.

Lee, S.-Y., Lim, Y.-S., and Jung, H.-Y. 2016. Molecular phylogeny and morphology of Mycosphaerella nawae, the causal agent of circular leaf spot on persimmon. Mycobiology 44:191-201.

Liu, Y. J., Whelen, S., and Hall, B. D. 1999. Phylogenetic relationships among ascomycetes: Evidence from an RNA polymerase II subunit. Mol. Biol. Evol. 16:1799-1808.

Maddison, W. P., and Maddison, D. R. 2011. Mesquite: A modular system for evolutionary analysis. Version 2.75 . http://mesquiteproject.org.

Moncalvo, J. M., Wamg, H. H., and Hseu, R. S. 1995. Phylogenetic relationships in Ganoderma inferred from the internal transcribed spacers and $25 \mathrm{~S}$ ribosomal DNA sequences. Mycologia 87:223-238.

Nilsson, R. H., Kristiansson, E., Ryberg, M., Hallenberg, N., and Larsson, K.-H 2008. Intraspecific ITS variability in the Kingdom Fungi as expressed in the international sequence databases and its implications for molecular species identification. Evol. Bioinform. 4:193-201.

Pretorius, M. C., Crous, P. W., Groenewald, J. Z., and Braun, U. 2003. Phylogeny of some cercosporoid fungi from Citrus. Sydowia 55:286-305.

Quaedvlieg, W., Binder, M., Groenewald, J. Z., Summerell, B. A., Carnegie, A. J., Burgess, T. I., and Crous, P. W. 2014. Introducing the Consolidated Species Concept to resolve species in the Teratosphaeriaceae. Persoonia 33:1-40.

Quaedvlieg, W., Groenewald, J. Z., Jesús Yáñez Morales, M., and Crous, P. W 2012. DNA barcoding of Mycosphaerella species of quarantine importance to Europe. Persoonia 29:101-115.

Rambaut, A., and Drummond, A. 2009. FigTree v1. 3.1: Tree figure drawing tool. http://tree.bio.ed.ac.uk/software/figtree/ Institute of Evolutionary Biology, Edinburgh, UK

Ronquist, F., Teslenko, M., van der Mark, P., Ayres, D. L., Darling, A., Höhna, S., Larget, B., Liu, L., Suchard, M. A., and Huelsenbeck, J. P. 2012. MrBayes 3.2: Efficient Bayesian phylogenetic inference and model choice across a large model space. Syst. Biol. 61:539-542.

Savi, D. C., Shaaban, K. A., Gos, F. M. W. R., Ponomareva, L. V., Thorson, J. S. Glienke, C., and Rohr, J. 2018. Phaeophleospora vochysiae Savi \& Glienke sp. nov. isolated from Vochysia divergens found in the Pantanal, Brazil, produces bioactive secondary metabolites. Sci. Rep. 8:3122.

Schoch, C. L., Seifert, K. A., and Huhndorf, S., Robert, V., Spouge, J. L., Levesque, C. A., Chen, W., and Fungal Barcoding Consortium. 2012. Nuclear ribosomal internal transcribed spacer (ITS) region as a universal DNA barcode marker for Fungi. Proc. Natl. Acad. Sci. USA 109:6241-6246.

Stielow, J. B., Levesque, C. A., Seifert, K. A., Meyer, W., Iriny, L., Smits, D., Renfurm, R., Verkley, G. J. M., Groenewald, M., Chaduli, D., Lomascolo, A., Welti, S., Lesage-Meessen, L., Favel, A., Al-Hatmi, A. M. S., Damm, U., Yilmaz, N., Houbraken, J., Lombard, L., Quaedvlieg, W., Binder, M., Vaas, L. A. I., Vu, D., Yurkov, A., Begerow, D., Roehl, O., Guerreiro, M., 
Fonseca, A., Samerpitak, K., van Diepeningen, A. D., Dolatabadi, S., Moreno, L. F., Casaregola, S., Mallet, S., Jacques, N., Roscini, L., Egidi, E., Bizet, C., Garcia-Hermoso, D., Martín, M. P., Deng, S., Groenewald, J. Z., Boekhout, T., de Beer, Z. W., Barnes, I., Duong, T. A., Wingfield, M. J., de Hoog, G. S., Crous, P. W., Lewis, C. T., Hambleton, S., Moussa, T. A. A., Al-Zahrani, H. S., Almaghrabi, O. A., Louis-Seize, G., Assabgui, R., McCormick, W., Omer, G., Dukik, K., Cardinali, G., Eberhardt, U., de Vries, M., and Robert, V. 2015. One fungus, which genes? Development and assessment of universal primers for potential secondary fungal DNA barcodes. Persoonia 35:242-263.

Sung, G.-H., Sung, J.-M., Hywel-Jones, N. L., and Spatafora, J. W. 2007. A multigene phylogeny of Clavicipitaceae (Ascomycota, Fungi): Identification of localized incongruence using a combinational bootstrap approach. Mol. Phylogenet. Evol. 44:1204-1223.

Tamura, K., Stecher, G., Peterson, D., Filipski, A., and Kumar, S. 2013. MEGA6: Molecular Evolutionary Genetics Analysis Version 6.0. Mol. Biol. Evol. 30: 2725-2729.

Taylor, J. E., and Crous, P. W. 1999. Phaeophleospora faureae comb. novo associated with leaf spots on Faurea saligna (Proteaceae), with a key to the species of Phaeophleospora. Fungal Divers. 3:153-158.

Verkley, G. J., Crous, P. W., Groenewald, J. Z., Braun, U., and Aptroot, A. 2004. Mycosphaerella punctiformis revisited: Morphology, phylogeny, and epitypification of the type species of the genus Mycosphaerella (Dothideales, Ascomycota). Mycol. Res. 108:1271-1282.

Videira, S. I. R., Groenewald, J. Z., Braun, U., Shin, H. D., and Crous, P. W. 2016 All that glitters is not Ramularia. Stud. Mycol. 83:49-163.

Videira, S. I. R., Groenewald, J. Z., Nakashima, C., Braun, U., Barreto, R. W., de Wit, P. J. G. M., and Crous, P. W. 2017. Mycosphaerellaceae - Chaos or clarity? Stud. Mycol. 87:257-421.

Vilgalys, R., and Hester, M. 1990. Rapid genetic identification and mapping of enzymatically amplified ribosomal DNA from several Cryptococcus species. J. Bacteriol. 172:4238-4246.

Wang, L.-W., Wang, J.-L., Chen, J., Chen, J.-J., Shen, J.-W., Feng, X.-X., Kubicek, C. P., Lin, F.-C., Zhang, C.-L., and Chen, F.-Y. 2017. A novel derivative of (-) mycousnine produced by the endophytic fungus Mycosphaerella nawae, exhibits high and selective immunosuppressive activity on T cells. Front. Microbiol. $8: 1251$.

Weir, B. S., Johnston, P. R., and Damm, U. 2012. The Colletotrichum gloeosporioides species complex. Stud. Mycol. 73:115-180.

White, T. J., Bruns, T., Lee, S. B., and Taylor, J. W. 1990. Amplification and direct sequencing of fungal ribosomal RNA genes for phylogenetics. Pages 315-322 in: PCR Protocols: A Guide to the Methods and Applications. M. A. Innis, D. H. Gelfand, J. J. Sninsky, and T. J. White, eds. Academic Press, San Diego, CA. 